\title{
Pre- and Postnatal Development of GABA Receptors in Macaca Monkey Visual Cortex
}

\author{
C. Shaw, ${ }^{1}$ L. Cameron, ${ }^{1}$ D. March, ${ }^{1}$ M. Cynader, ${ }^{1}$ B. Zielinski, ${ }^{2, a}$ and A. Hendrickson ${ }^{2}$ \\ 'Departments of Ophthalmology and Physiology, University of British Columbia, Vancouver, Canada V6T $1 Z 3$ and \\ ${ }^{2}$ Departments of Biological Structure and Ophthalmology, University of Washington, Seattle, Washington 98195
}

GABA is a putative inhibitory neurotransmitter in adult mammalian visual cortex but also has been implicated as playing a crucial role in cortical information processing during development. In order to understand better the role of GABA during primate visual cortex development, we have examined the time course of $\mathrm{GABA}_{A}$ and $\mathrm{GABA}_{B}$ receptor ontogenesis in 18 Macaca nemestrina monkeys ranging from fetal day 61 (F61d) to adulthood. The GABA and benzodiazepine binding sites of the $\mathrm{GABA}_{\mathrm{A}}$ receptor were detected by ${ }^{3} \mathrm{H}$-muscimol ( ${ }^{3} \mathrm{H}-\mathrm{MS}$ ) and ${ }^{3} \mathrm{H}$-flunitrazepam $\left({ }^{3} \mathrm{H}-\mathrm{FZ}\right)$, re-

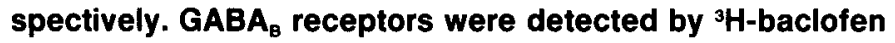
( ${ }^{3} \mathrm{H}-\mathrm{BA}$ ). All ligands were visualized by in vitro autoradiography. Quantitative analysis of film density was done to compare laminar changes during pre- and postnatal development. Saturation binding experiments were done for MS and $F Z$ binding sites to determine receptor number $\left(B_{\max }\right)$ and affinity $\left(K_{d}\right)$ at selected pre- and postnatal ages.

Both MS and FZ binding sites were present at F61d-72d throughout the cortical plate and marginal zone. FZ binding sites were more dense than MS binding sites over the cortical plate at young ages and were especially dense over the marginal zone. FZ binding sites also were present in lesser amounts over the subplate and intermediate zone, but not over the subventricular zone. By F119d-126d, layer 4 could be distinguished by its higher density for both ligands. The basic adult laminar pattern was established for both MS and BZ binding sites by birth (birth $=$ F165d-170d). After birth, MS density increases dramatically in all layers, but layer $4 \mathrm{C}$ remains most dense to adulthood. FZ labeling is heavy in both layers 4 and 3 at birth but after 4 weeks after birth (P4 wk) it declines somewhat in the supragranular layers so that layer 4C now predominates. Labeling in layers $5 / 6$ virtually disappears after birth. BA binding sites were present at

Received Apr. 29, 1991; revised July 23, 1991; accepted July 24, 1991.

This research was supported by NIH Operating Grants EY01208 and EY04536 (A.H.), in part by NIH Training Grant EY01730, Canadian MRC PG-29, a BC Health Care Research Foundation Operating grant and a BC Medical Services Foundation operating grant (C.S.), and in part by EY01730. C.S. is a BC Health Care Research Foundation Scholar. The technical assistance of Andra Erickson and Janet Stolt, and the cooperation of Judy Johnson and Whallen Kieller, Tissue Program coordinators at the Regional Primate Research Center, University of Washington (RR00166), is gratefully acknowledged. We thank Beckman Instruments and Drs. B. Bressler and S. Vincent for their generous loan of equipment, and the faculty, staff, and students of the Department of Anatomy, UBC, for their assistance.

Correspondence should be addressed to Dr. Anita Hendrickson, Biological Structure, SM-20, University of Washington, Seattle, WA 98195.

a Present address: Department of Biological Sciences, University of Windsor, Ontario, Canada N9B 3PY.

Copyright (c) 1991 Society for Neuroscience $0270-6474 / 91 / 113943-17 \$ 05.00 / 0$
F126d, at which time layer 4 was slightly lighter than the remainder of striate cortex; this laminar pattern remained basically the same throughout our series to adulthood.

Competitive binding of agonist and antagonists for the $\mathrm{GABA}_{\mathrm{A}}$ receptor showed that $\mathrm{MS}$ binding characteristics were similar at F126d and P8.5 years (yr). MS binding site $B_{\max }$ was about $8 \%$ of adult values at F72d, $24 \%$ by $F 126 \mathrm{~d}$, and $56 \%$ at $F 152 d . B_{\max }$ then rose rapidly after birth to peak at P18wk at $169 \%$ of adult values, and then declined to P1yr. A second peak of $143 \%$ was found around P3.5yr, with adult values reached by P8.5yr. $K_{d}$ values for MS at F 126d showed evidence for two binding sites ( $34 \mathrm{~nm}$ and $4 \mathrm{nM}$ ) that existed up to P1d, and only one site (26-65 nM) after this age. The $B_{\max }$ for $F Z$ was $27 \%$ of adult values at $F 126 \mathrm{~d}$, peaked at $113 \%$ adult value at P18wk, and declined slowly to adult levels by P8.5yr. $K_{d}$ values for FZ found one site at all ages. Binding for $F Z$ is proportionately higher in early development with a ratio of 1:2-3 FZ:MS, but in the postnatal cortex MS binding dominates with a ratio of 1:4-6 FZ:MS.

The present study demonstrates the early prenatal occurrence in monkey visual cortex of both the MS and FZ binding sites of the $\mathrm{GABA}_{A}$ receptor and also of the GABA receptor. The $\mathrm{GABA}_{A}$ receptor first appears near the age when GABAergic neurons can be detected immunocytochemically (Hendrickson et al., 1988; Meinicke and Rakic, 1989), but before synapses are found in significant numbers (Zielinski and Hendrickson, 1990). Although GABA $_{A}$ receptors are normally associated with inhibitory synaptic circuits, these data suggest that the initial expression of GABA receptors is not dependent on synaptic contact and that GA$B_{A}$ and its receptors may play some neurotrophic role in early cortical development. Postnatal changes in receptor distribution and number are more closely correlated with synaptic density changes.

The macaque monkey striate cortex (primary visual, V1, or area 17 ) is one of the most widely studied systems in developmental neuroscience. Visual pathways to and from cortex have been mapped (reviewed in Hendrickson et al., 1978; Tigges and Tigges, 1985; Kaas and Huerta, 1988), there is a considerable data base on adult anatomy and physiology (Hubel, 1982; Blasdel and Fitzpatrick, 1984; Horton and Hedley-Whyte, 1984; Sillito, 1984; Hendrickson, 1985; Allman and McGuiness, 1988; Livingstone and Hubel, 1988; Lund, 1988), and the normal development of these parameters is known (reviewed in Rakic, 1977; LeVay et al., 1980; Boothe et al., 1985; Boothe, 1988). Many of thesc studies indicate that there is a marked similarity between ma- 
caque and human visual systems, making the macaque a valuable model for invasive and experimental studies. This similarity is important because modification of retinal input during early postnatal development causes marked abnormalities in macaque cortical structure and function and produces symptoms identical to human visual amblyopias (discussed in LeVay et al., 1980; Wiesel, 1982; Hendrickson et al., 1987; Kiorpes et al., 1987; Harwerth et al., 1989).

Much recent research in this field has focused on defining the chemical circuitry of visual cortex, especially which neurons contain identified neurotransmitters and where receptors for neurotransmitters and/or neuromodulators are localized. Perhaps the best understood neurotransmitter for these studies is the inhibitory amino acid GABA (Houser et al., 1984; Somogyi, 1989). In striate cortex, this neurotransmitter is found within a heterogeneous population of nonpyramidal aspiny stellate neurons intrinsic to the cortex that label both for glutamate decarboxylase, the synthetic enzyme for GABA (Hendrickson et al., 1981; Fitzpatrick et al., 1987), and for GABA itself(Fitzpatrick et al., 1987; Hendry et al., 1987; Somogyi, 1989). GABAergic neurons comprise $15-20 \%$ of the neuronal population in all layers except layer 1 , in which $90 \%+$ of the neurons are GABAergic. In striate cortex of both cat and monkey, the synapses formed by these neurons are almost exclusively of the symmetric type and terminate on dendritic spines, shafts, cell bodies, and initial axon segments (Ribak, 1978; Houser et al., 1984; Somogyi and Hodgson, 1985; LaVie and Hendrickson, 1986; Somogyi, 1989). There is also abundant electrophysiological evidence that GABA is an inhibitory neurotransmitter in cat striate cortex, heavily influencing directional and orientation specificity but with less influence on ocular dominance (discussed in Sillito, 1984; Wolf et al., 1986). Recent work in brain slices indicates that GABA has an inhibitory function in human cerebral cortex as well (McCormick, 1989). The results of combining Golgi impregnation or intracellular filling with EM immunocytochemical labeling suggest that each morphological type of GABAergic neuron has a characteristic pattern of axon termination that is specific for one part of the postsynaptic neuron (reviewed by Somogyi, 1989). This correlation should help explain the role of GABA neurotransmission in determining physiological specificity when these anatomical circuits are better analyzed.

As would be expected from the large number of GABAergic neurons, the adult primate striate cortex is well endowed with muscimol (MS)-binding sites that label the GABA-binding component of $\mathrm{GABA}_{\mathrm{A}}$ receptors, and with benzodiazepine-binding sites that label another component of the $\mathrm{GABA}_{\mathrm{A}}$ receptor complex (Braestrup et al., 1977; Shaw and Cynader, 1986; Rakic et al., 1988; McCormick, 1989). Antisera specific for the $\mathrm{GABA}_{\mathrm{A}}$ receptor label all cortical layers to varying degrees (Hendry et al., 1990). Baclofen (BA)-binding sites that label the putative $\mathrm{GABA}_{\mathrm{B}}$ receptor also are present but are less prominent (McCormick, 1989; Shaw et al., 1989, 1990). GABA Gd $_{\text {GABA }}$ receptor subtype activation typically causes inhibition via hyperpolarization of target neurons (recently reviewed in Kuman et al., 1987; Bowery, 1989; Matsumoto, 1989; Sieghart, 1989; Olsen and Tobin, 1990). Scharfman and Sarvey (1987) have also shown that $\mathrm{GABA}_{\mathrm{A}}$ receptors on distal dendrites mediate depolarizing responses while those on somata and proximal dendrites mediate hyperpolarization. Activation of the MSbinding, bicuculline-sensitive $\mathrm{GABA}_{\mathrm{A}}$ receptor leads to an inwardly directed chloride current, while activation of the BAbinding, bicuculline-insensitive $\mathrm{GABA}_{\mathrm{B}}$ receptor initiates a
G-protein cascade that results in increased potassium or decreased calcium conductance. Benzodiazepine receptors are usu-

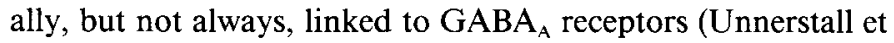
al., 1981; Richards and Mohler, 1984; Shaw et al., 1987) and appear to modulate their sensitivity (Costa et al., 1978). In order to distinguish between a true receptor and a binding site, it is necessary to identify the pharmacological profile of agonist and antagonist displacement of the labeled ligand, and the receptor affinity $\left(K_{d}\right)$ and number $\left(B_{\max }\right)$. Br zause such criteria have not been met by all the studies cited below, we will use the less specific term "binding site" for ${ }^{3} \mathrm{H}$-MS binding that labels GA$\mathrm{BA}_{\mathrm{A}}$ receptors and ${ }^{3} \mathrm{H}$-flunitrazepam $\left({ }^{3} \mathrm{H}-\mathrm{FZ}\right)$ binding as a marker of benzodiazepine receptors.

Surprisingly little is known about the normal developmental sequence of GABA receptors in monkey striate cortex. Two recent reports using monoclonal antisera to $\mathrm{GABA}_{\mathrm{A}}$ and benzodiazepine receptors (Meinecke and Rakic, 1989; Huntley et al., 1990) detect labeling in several areas of macaque cortex at the relatively late age of fetal day 100 (F100d)-131d (birth $=$ F165d-170d). Autoradiographic ligand binding studies (Shaw et al., 1989, 1990) detected FZ and MS binding sites in striate cortex by F72d, which is close to the age when GABAergic neurons are first stained immunocytochemically (Hendrickson et al., 1988; Meinicke and Rakic, 1989). There are several GA$\mathrm{BA}_{\mathrm{A}}$ receptor membrane binding studies in developing human cortex, but no autoradiographic studies have been reported. Human cerebral cortex at fetal week 15 (F15wk) contains 6\% of adult benzodiazepine levels (Aaltonen et al., 1983). In human frontal cortex (Brooksbank et al., 1981, 1982), MS binding was $9 \%$ of adult in the F18wk-28wk prenatal group, $47 \%$ in the F26wk-42wk perinatal group, and $97 \%$ by postnatal (P)4wk$8 \mathrm{mo}$. On the other hand, FZ binding is $9 \%$ of adult in early prenatal life but is only $22 \%$ in the perinatal and $55 \%$ in the postnatal group, indicating that the benzodiazepine component of the $\mathrm{GABA}_{\mathrm{A}}$ receptor is somewhat slower to complete development. By the second half of gestation, MS binding is about twice that of FZ, and this ratio remains constant into adulthood, although overall MS binding increases 10 -fold and FZ binding increases 6-fold from F18wk to adult. Glutamic acid decarboxylase (GAD) activity in cortical neurons is very slow to develop (Brooksbank et al., 1981), being only 5\% of adult in the prenatal group, and still only $38 \%$ of adult by P8mo. The age at which GABAergic neurons first appear in human cortex is not known.

The data on $\mathrm{GABA}_{\mathrm{A}}$ receptor development in cat and rodent cortex is much more extensive. Whole rat brain demonstrates benzodiazepine binding at 5\% of adult levels by F14d (Braestrup and Nielsen, 1978) or F15d (Coyle and Fnna, 1976), while mouse brain at F17d contains $10 \%$ of adult levels (Regan et al., 1980). On the other hand, MS binding in rat cortex still was less than $10 \%$ at $\mathrm{P} 2 \mathrm{~d}$, while $\mathrm{FZ}$ binding had reached $50 \%$ of adult $(\mathrm{Pa}-$ lacios et al., 1979). The only study using autoradiographic methods to determine prenatal laminar developmental patterns is that of Schlumpf et al. (1983); postnatal ages were not included. They find a rostral-caudal developmental gradient for FZ binding in that labeling appeared in frontal cortex at F16d but did not reach occipital cortex until F21d. At F16d, only the marginal zone or future layer 1 was labeled, but by F18d the subplate and/or layer 6 was also labeled. The cortical plate was not clearly labeled until F21d, when the deeper older layers were more dense than the upper younger layers. Zones containing prolifcrating stem cells wcrc never labeled. Neurons immunocytochemically labeled for GABA are found within the developing 
rat marginal zone at F16d and in cortical plate by F18d-21d (Lauder et al., 1986; Van Eden et al., 1989), suggesting in rodents that GABAergic neurons and receptors appear at the same time. Prenatal studies of receptor development have not been performed in the cat. Postnatally, MS binding is $41 \%$ of adult levels by $\mathrm{P} 3 \mathrm{~d}$ and reaches $131 \%$ of adult at $\mathrm{P} 14 \mathrm{wk}$, while $\mathrm{FZ}$ binding is $18 \%$ at $\mathrm{P} 3 \mathrm{~d}$ and peaks at $133 \%$ at P8wk. Both decline by $\mathrm{P} 1 \mathrm{yr}$ to adult levels (Shaw et al., 1984, 1986, 1987). GABA neurons are present in the subplate of cat visual cortex by 1 week before birth (Chun and Shatz, 1989), but when they first appear in the cat cortical plate is not yet clear.

These data indicate that both GABA neurons and $\mathrm{GABA}_{\mathrm{A}}$ receptors are found prenatally in several mammalian spccies. For monkeys, the exact developmental sequence of $\mathrm{GABA}_{\mathrm{A}}$ receptors has yet to be determined, there is little data on laminar sequences, and $\mathrm{GABA}_{\mathrm{B}}$ receptor development has not been studied. It is important to determine this sequence more accurately because GABAergic neurotransmission is altered in some forms of visual deprivation and postnatal changes in layer 4 could play a role in postnatal visual deprivation syndromes (Hendry and Jones, 1986; Skangiel-Kramska and Kossut, 1984; Shaw and Cynader, 1988; Mower and Christen, 1989; Hendry et al., 1990). The present article will describe $\mathrm{GABA}_{\mathrm{A}}$ receptor characteristics and the laminar distributions for MS, BA, and FZ binding sites in Macaca nemestrina striate cortex from early gestation to adulthood. Because the time of cell generation (Rakic, 1977) and the time of the appearance of GABA immunoreactivity in neurons is known (Hendrickson et al., 1988; Meineicke and Rakic, 1989) and there are quantitative data regarding synaptic development at the same ages in macaque monkey (O'Kusky and Colonnier, 1982; Rakic et al., 1986; Zielinski and Hendrickson, 1990), it is possible to compare these receptor data with neuronal and synaptic development to reveal the sequence of appearance and possible interdependencies for the GABAergic neurotransmitter system.

\section{Materials and Methods}

Tissue preparation. For receptor studies, 18 normal colony-bred Macaca nemestrina monkeys were used. They were killed at prenatal F61d, $72 \mathrm{~d}, 119 \mathrm{~d}, 126 \mathrm{~d}$, and 152d; postnatal P1d and 1.5d; 4, 7, 18, 32, 36, and 58 weeks; juveniles at 2.6,3.3, and 3.5 years; and full adults of 8.5 and 11.3 years. The gender of the two youngest animals was not determined, the F119d, P7wk, one P36wk, and the 2.6yr and $8.5 \mathrm{yr}$ animals were males, and the remainder were females. Prenatal animals were the result of timed matings such that the ages were known within $\pm 1 \mathrm{~d}$. In this colony, birth occurs at F165d-170d. Postnatal animals were born spontaneously and were at or above the norms for birth weights in the Regional Primate Center colony to exclude premature animals. Bccause of the difficulty and expense in obtaining large numbers of fetal and infant monkeys, we chose to have our series cover as many time points as possible along the prolonged period of primate visual development. However, the variation in our data can be compared in closely matched pairs at several ages (F119d-126d; P1d-1.5d; P32wk-36wk, and P3.3yr-3.5yr).

For cesarian section, the pregnant female monkey was tranquilized with ketamine, intubated, and then deeply anesthetized with halothane/ $\mathrm{O}_{2}$ mixture. The fetus was delivered under aseptic conditions and given a lethal intraperitoneal dose of barbiturate. Postnatal animals were killed with intravenous barbiturate. The brains were removed immediately after death, and striate cortex blocks from known striate cortical areas were oriented in cryostat freezing compound in disposable paper beakers and rapidly frozen in liquid Freon at $-45^{\circ} \mathrm{C}$. All frozen blocks were stored at $65^{\circ} \mathrm{C}$ for $1-12$ weeks before the first assays for receptor binding were done. Because of the difficulties of obtaining a series of monkey fetuses, initial storage times varied between age, but in no systematic way. No variations in the distribution of binding sites could be detected that correlated with differences in storage times, nor has a recognizable change occurred in binding characteristics over time. All assays were performed on $20-\mu \mathrm{m}$-thick frozen sections that were cut on a cryostat, thaw mounted onto subbed glass slides, and stored for $1-7 \mathrm{~d}$ at $-20^{\circ} \mathrm{C}$ until assayed. The storage of visual cortex tissues at $-25^{\circ} \mathrm{C}$ in the original blocks or as cut sections does not appear to alter significantly either ${ }^{3} \mathrm{H}-\mathrm{MS}$ or ${ }^{3} \mathrm{H}-\mathrm{FZ}$ binding (see Shaw and Cynader, 1988 , and Shaw et al., 1987, respectively.) Nevertheless, quantitative binding assays in the present experiments were performed on tissue that was sectioned within the same $48 \mathrm{hr}$ period and stored for no more than 1 week. Although some saturation binding assays were run separately, the sections from all animals were treated equivalently. Preliminary studies showed that extraction of the sections to remove lipids (myelin artifact) had little effect on the resulting film density pattern. Because lipid extraction caused deterioration of morphological integrity, especially in prenatal tissue, it was not used for the autoradiographs presented in this article.

Binding assays. Each binding assay included sections from all ages. These assays follow the protocols used previously to characterize GA$\mathrm{BA}_{\mathrm{A}}$ receptors in cat (Needler et al., 1984; Shaw et al., 1987) and adult monkey striate cortex (Shaw and Cynader, 1986). GABA Grotocols $_{\mathrm{B}}$ were based on our characterization of these receptors in cat visual cortex (C. Shaw and L. Cameron, unpublished observations). Details of each binding protocol are given in Table 1. Following the postincubation rinse, the sections were rapidly dried under a stream of cool air and stored overnight with desiccant. Slide-mounted sections destined for autoradiography were taped onto heavy cardboard and overlain with tritium-sensitive film (Amersham Hyperfilm); a slide containing ${ }^{3} \mathrm{H}$ standards (Amersham) was included on each film. At least two different exposures were made from each assay. Once suitable autoradiograms had been generated, the original sections were then stained with cresyl violet. Both the film and corresponding stained section were photographed at the same magnification, and photographic prints of the two were aligned to determine laminar boundaries. For each receptor population, sections from animals of different ages were exposed to Hyperfilm for the same period, usually on the same sheet of film.

Characterization and quantitative determinations of receptor number $\left(B_{\max }\right)$ and affinity $\left(K_{d}\right)$ were made by saturation binding assays using ${ }^{3} \mathrm{H}$-MS and ${ }^{3} \mathrm{H}-\mathrm{FZ}$ (New England Nuclear) as described in detail elsewhere (Needler et al., 1984; Shaw et al., 1987). In brief, for each animal, total binding at a range of ligand concentrations was determined in three to four sections. Nonspecific binding was determined in two sections by coincubation with the appropriate displacer (Table 1). In each individual section, the same region of layers 1-6 from striate cortex was scraped from the slide onto filter paper and placed in scintillation fluid (New England Nuclear, Formula 963). Quantitative binding in the youngest animal, F72d, was obtained from the cortical plate and marginal zone only. Bound radioactivity was counted in a scintillation counter, and Eadie-Hofstee analysis for a single site was performed by the methods of Zivin and Waud (1982). Multiple binding site curve fitting was performed using best-fit correlation coefficient values for a series of separately determined partial binding curves (Hunston, 1975). Matching alternate sections from cach cortical block were assayed for protein content (Lowry et al., 1951), and the number of receptors is expressed as $\mathrm{fmol} / \mathrm{mg}$ protein. See captions of Figures $4-6$ for further details.

Quantitative analysis of laminar binding density on film autoradiograms was done using an Imaging Research Inc. (St. Catherine's, Ontario, Canada) image analysis system calibrated with the included ${ }^{3} \mathrm{H}$ standards (Amersham Microscales; 3.03-109.08 $\mathrm{nCi} / \mathrm{mg}$ actual polymer activity). A density profile was constructed across all cortical layers in one representative section of striate cortex from each animal. The calculated values are given in Table 3 .

\section{Results}

\section{Qualitative changes with age}

$G A B A_{A}$ receptors in the prenatal monkey striate cortex. Figure 1 shows cresyl violet-stained sections in the left column, ${ }^{3} \mathrm{H}$ MS binding sites in the center column, and ${ }^{3} \mathrm{H}-\mathrm{FZ}$ binding sites in the right column. Ages are F61d, F72d, F126d, and F152d from top to bottom, respectively. Figure 2 continues this developmental sequence after birth, with P1.5d, P4wk, P18wk, and P3.5yr shown from top to bottom, respectively. In Figures 

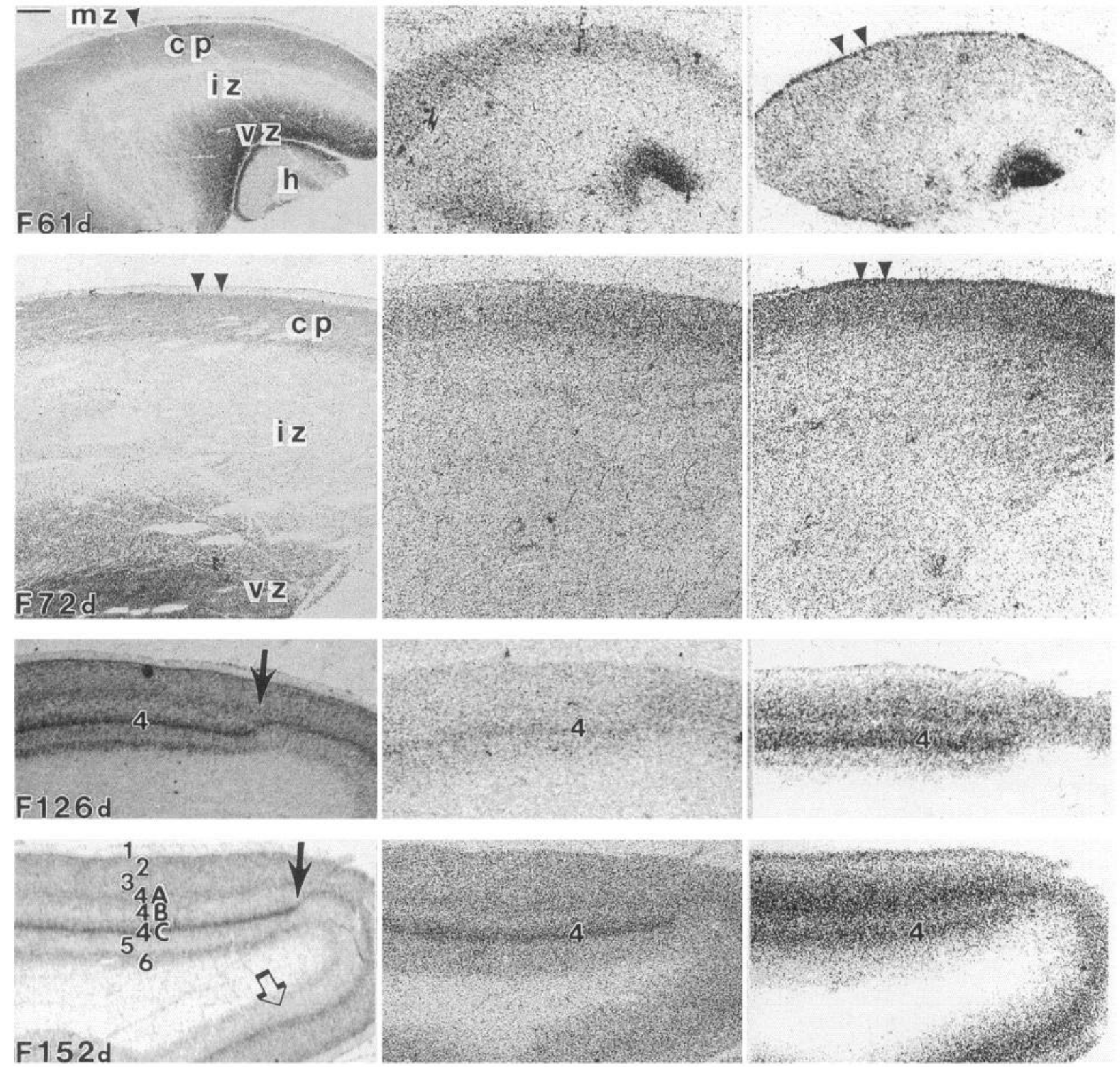

Figure 1. Autoradiographic distribution of $\mathrm{GABA}_{\mathrm{A}}$ receptors before birth in Macaca nemestrina visual cortex. This plate shows sections of macaque visual cortex at F61d (top row), F72d (second row), F126d (third row), and F152d (bottom row). The left column shows sections stained for cresyl violet; the middle column, sections labeled by ${ }^{3} \mathrm{H}$-MS and the right column, sections labeled by ${ }^{3} \mathrm{H}-\mathrm{FZ}$. Frozen sections were cut from unfixed tissue, and these slide-mounted sections were incubated as described in Table 1 . In the youngest cortex, the marginal zone $(m z)$, cortical plate $(c p)$, subplate-intermediate zone (iz), and ventricular zone $(v z)$ are indicated in the cresyl violet-stained section. The $m z$ is marked by arrowheads in the FZ section. In the F61d brain, the underlying hippocampus $(h)$ is heavily labeled and should not be confused with the overlying unlabeled $v z$. The high level of ${ }^{3} \mathrm{H}$-MS labeling over $i z$ at the two youngest ages is background that was created in printing the relatively lightly labeled films at this age. In F152d, all layers are marked on the cresyl violet section; in other photos layer 4C is marked by 4. The striate-prestriate border is indicated by a solid arrow, and in the bottom row, prestriate area 18 is marked by an open arrow. All photos are 10×; scale bar in upper left corner equals $500 \mu \mathrm{m}$.

1 and 2 , reading across the rows allows a comparison of ligands at the same age, while reading down the rows compares agerelated changes. In the following description, the terms "labeling density" or "heavy versus light" will be used to indicate qualitative differences in film density for a single section. Because film density is related to binding-site number (Baskin and Dorsa, 1986), computer-assisted quantitative determinations of agerelated changes in receptor density within individual layers were done and are discussed below.

At the youngest age examined thus far, F61d (Fig. 1, top row), cresyl violet staining shows a dense band of neurons consisting of the superficial marginal zone and a thin cortical plate on the surface of the cerebral vesicle. This band is underlain by the scattered neurons and fibers of the subplate/intermediate zone and even deeper by the subventricular zone that gives rise to neurons that migrate across the intermediate zone into the cortical plate. The cortical plate forms the adult cerebral cortex by progressive sequential addition of neurons, beginning with layer 6 and ending with layer 2 . The marginal zone becomes layer 1 of adult cortex (Sidman and Rakic, 1973). At F61d, the cortical 

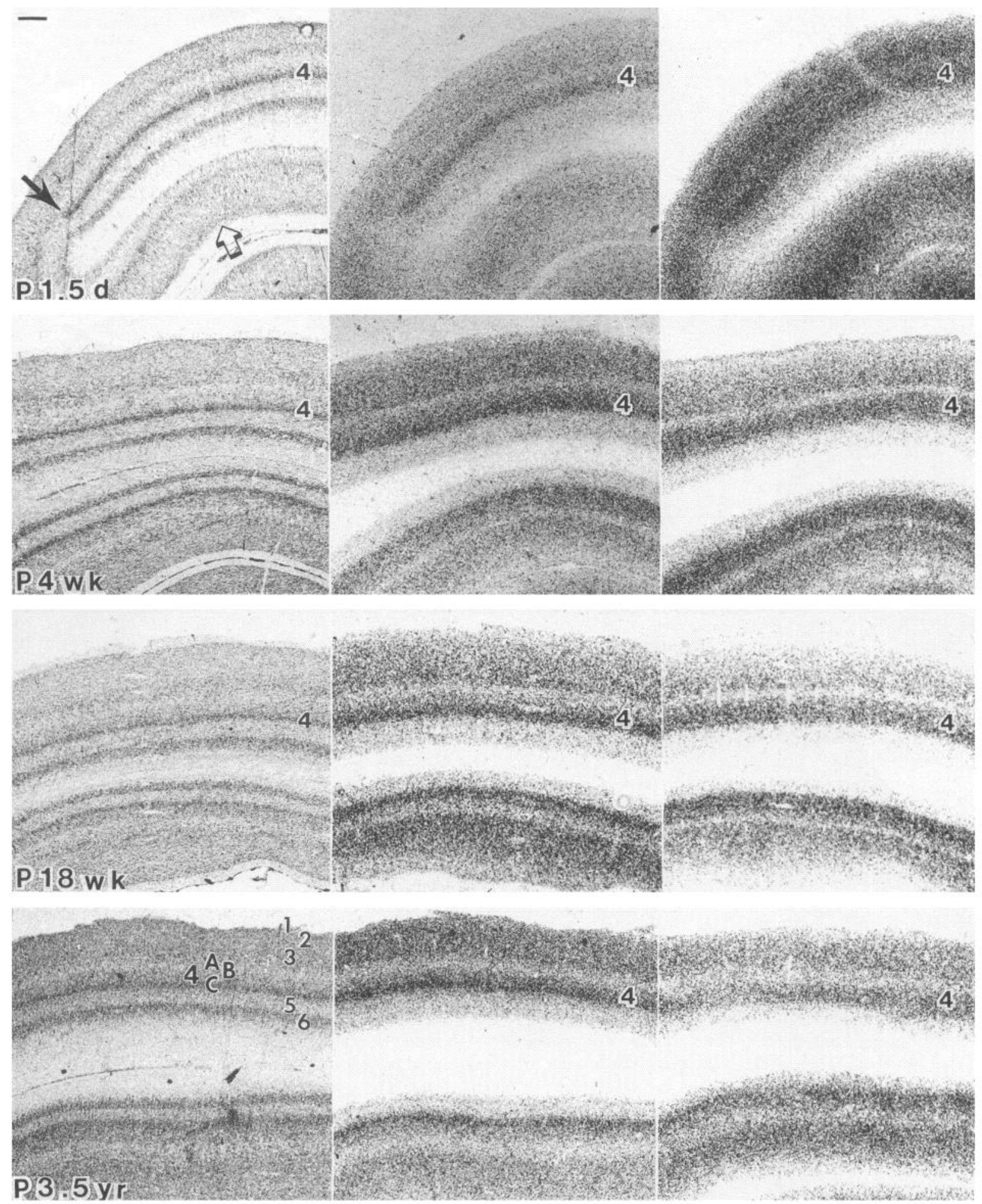

Figure 2. Autoradiographic distribution of $\mathrm{GABA}_{\mathrm{A}}$ receptors after birth in Macaca nemestrina visual cortex. This plate shows sections of macaque visual cortex at P1.5d (top row), P4wk (second row), P18wk (third row), and P3.5yr (bottom row). The cresyl violet section of P3.5yr has all layers marked; labels are otherwise the same as Figure 1. Scale bar, $500 \mu \mathrm{m}$.

plate contains mainly neurons that will form adult layers 6 and 5 (Rakic, 1977). Even at this young age, both MS and FZ binding sites are present. MS binding sites are confined to the cortical plate and marginal zone. FZ binding sites are heavy in the cortical plate but have the highest density in the outer portion of the marginal zone and also extend into the subplate/inter- laminar zone. The ventricular zone is not labeled for either ligand, although the underlying hippocampus is very heavily labeled for both ligands. At F72d, the binding patterns are similar, but FZ binding sites are somewhat more confined to the cortical plate.

By F126d, the cortex contains its full complement of neurons 


\begin{tabular}{|c|c|c|c|}
\hline Receptor & Ligand & Displacer & Conditions \\
\hline $\mathrm{GABA}_{\mathrm{A}}$ & $\begin{array}{l}{ }^{3} \mathrm{H}-\mathrm{Ms} \\
100 \mathrm{nM}^{a} \\
0.2-400 \mathrm{nM}^{b} \\
25 \text { and } 50 \mathbf{n M}^{c}\end{array}$ & $10^{-4} \mathrm{M}$ GABA & $\begin{array}{l}50 \mathrm{~mm} \text { Tris-citrate buffer, } \mathrm{pH} 7.0 \text {, at } 4^{\circ} \mathrm{C} \text {; } \\
\text { preincubation wash w/cold } 0.2 \% \\
\text { formaldehyde buffer for } 10 \mathrm{~min} ; 2 \times 5 \mathrm{~min} \\
\text { wash in buffer alone; } 30 \mathrm{~min} \text { incubation at } \\
4^{\circ} \mathrm{C} \mathrm{w} / 100 \mathrm{~nm}{ }^{3} \mathrm{H}-\mathrm{Ms} ; 3 \times 5 \mathrm{scc} \text { rinsc in } \\
\text { cold buffer. }\end{array}$ \\
\hline Benzodiazepine & $\begin{array}{l}{ }^{3} \mathrm{H}-\mathrm{FZ} \\
10 \mathrm{nM}^{a} \\
0.1-26 \mathrm{nM}^{b}\end{array}$ & $\begin{array}{l}3 \times 10^{-6} \mathrm{M} \\
\text { Clonezepam }\end{array}$ & $\begin{array}{l}50 \mathrm{~mm} \text { Tris- } \mathrm{HCl} \text { buffer, } \mathrm{pH} 7.0 \text {, at } 4^{\circ} \mathrm{C} \text {; } \\
\text { preincubation wash w/cold } 0.2 \% \\
\text { formaldehyde buffer for } 10 \mathrm{~min} ; 2 \times 5 \mathrm{~min} \\
\text { wash in buffer alone; } 60 \mathrm{~min} \text { incubation at } \\
4^{\circ} \mathrm{C} \mathrm{w} / 10 \mathrm{nM}{ }^{3} \mathrm{H}-\mathrm{FZ} ; 3 \times 30 \mathrm{sec} \text { rinse in } \\
\text { cold buffer. }\end{array}$ \\
\hline $\mathrm{GABA}_{\mathrm{B}}$ & $\begin{array}{l}{ }^{3} \mathrm{H}-\mathrm{BA} \\
50 \mathrm{nM}^{a}\end{array}$ & $10^{-4} \mathrm{M}$ GABA & $\begin{array}{l}50 \mathrm{mM} \text { Tris- } \mathrm{HCl} \text { buffer w/ } 2.5 \mathrm{mM} \mathrm{CaCl}, \mathrm{pH} \\
7.4 \text {, at } 20^{\circ} \mathrm{C} \text {; preincubation wash w/cold } \\
0.2 \% \text { formaldehyde buffer for } 10 \mathrm{~min} ; 2 \times \\
5 \mathrm{~min} \text { wash in buffer alone; } 60 \mathrm{~min} \\
\text { incubation at } 20^{\circ} \mathrm{C} \mathrm{w} / 50 \mathrm{nM}{ }^{3} \mathrm{H}-\mathrm{BA}+40 \\
\mu \mathrm{M} \text { isoguvacine; } 3 \times 5 \mathrm{sec} \text { rinse in cold } \\
\text { buffer. }\end{array}$ \\
\hline
\end{tabular}

\footnotetext{
"Ligand concentration for film autoradiography.

"Ligand concentrations for $B_{\max }$ and $K_{d}$ determinations.

$c$ Ligand concentrations for displacement studies. Radioligand concentrations for the displacement curves were chosen to be near predicted $K_{d}$ values, especially for the younger animal (F72d) where $B_{\text {max }}$ was relatively small, in order to ensure dpm levels well above background.
}

(Rakic, 1977) and the adult striate cortex layers can be identified (Fig. 1, third row). The border between striate (to left) and prestriate (to right) cortex is indicated by a solid arrow. MS labeling still is quite sparse but is present in all layers, although now it is somewhat denser in layer $4 \mathrm{C}$ of striate cortex (marked by " 4 " in Figs. 1 and 2). Prestriate cortex is more densely labeled than striate at this age, particularly in the upper layers. FZ binding in cortex is strikingly increased in density and shows a clearly laminated distribution, with layers $4 \mathrm{~A} /$ deep 3 and $4 \mathrm{C}$ heavier than the other layers, while layer 4B stands out as a pale band between these layers. The band of FZ labeling over layer $4 \mathrm{C}$ is much wider than for $\mathrm{MS}$, and covers $4 \mathrm{C} \alpha$ and $4 \mathrm{C} \beta$. Comparison with cresyl violet-stained sections indicates that FZ binding sites extend somewhat below layer 6 into the developing white matter, but deeper white matter is now only lightly labeled. Prestriate cortex is less obviously laminated, but upper layers are much darker than lower.

At F152d, the cortex has increased in thickness, but lamination has changed relatively little from F126d. Overall MS binding site density has increased so that layers deep 3/4A can be detected by an increase in density compared to $4 \mathrm{~B}$, which remains light. Layer $4 C$, particularly its deeper subdivision $4 C \beta$, remains the layer with the heaviest MS labeling. FZ labeling is still much heavier than MS overall, with a thick band over both $4 C \alpha$ and $4 C \beta$ and an extension of heavy labeling into layer 3 . Prestriate cortex (open arrow) also shows increased FZ labeling, with a darker band now present over layer 4/deep 3 .

After birth (Fig. 2), cortical lamination as shown by cresyl violet staining changes relatively little. In the first months after birth, there appears to be a general trend in which MS labeling density increases with age, while $\mathrm{FZ}$ labeling density stabilizes or decreases slightly. Shortly after birth at P1.5d, MS labeling is somewhat heavier in striate layers $4 \mathrm{C}$ and $2 / 3$, and in prestriate cortex middle layers. A comparison of Figures 1 and 2 suggests that before birth MS binding sites are found mainly over $4 \mathrm{C} \beta$, but after birth extend into or increase over $4 \mathrm{C} \alpha$. Layer $4 \mathrm{C} \beta$ predominates for MS labeling at all older ages, in substantial agreement with Shaw and Cynader (1986) and Rakic et al. (1988). At $\mathrm{P} 4 \mathrm{wk}$, there is a dramatic increase in MS labeling density in layers $2 / 3$ to a level similar to layer $4 \mathrm{C}$. At later ages, MS labeling in the upper layers is somewhat variable, but deep $4 \mathrm{C}$ is always the most heavily labeled layer after birth.

Just after birth, FZ labeling density is high in all layers except over layer 1 . With age, it decreases in the upper layers relative to layer $4 \mathrm{C}$, and it is not until $\mathrm{P} 4 \mathrm{wk}$ that $\mathrm{FZ}$ labeling is heaviest in $4 \mathrm{C} \alpha / \beta$. This progression continues so that by P18wk layers 1-3 are light relative to $4 \mathrm{C}$, although they are somewhat darker again in the adult. FZ labeling in layers $5 / 6$ is barely detectable by $\mathrm{P} 4 \mathrm{wk}$ and remains light into adulthood.

In the age groups with two or more animals (F119d-126d, P1d-1.5d, P32wk-36wk, juvenile, and adult), there was no difference between animals of the same age in the laminar distribution of MS or FZ labeling. Quantitative measures also were very similar except for one juvenile female (see below).

Throughout this developmental sequence there is no consistent evidence for "patchiness" in the binding pattern in any layer for either MS or FZ that would suggest a correlation with developing ocular dominance columns. The blocks at F126d, F152d, and P1.5d in Figures 1 and 2 were cut parallel to the long axis of the ocular dominance columns as they terminate at the striate-prestriate border (Hubel, 1982), an orientation that is not optimal to visualize columns. However, the older cortex blocks in Figure 2 were from calcarine cortex on the horizontal meridian, and they were oriented such that ocular dominance 

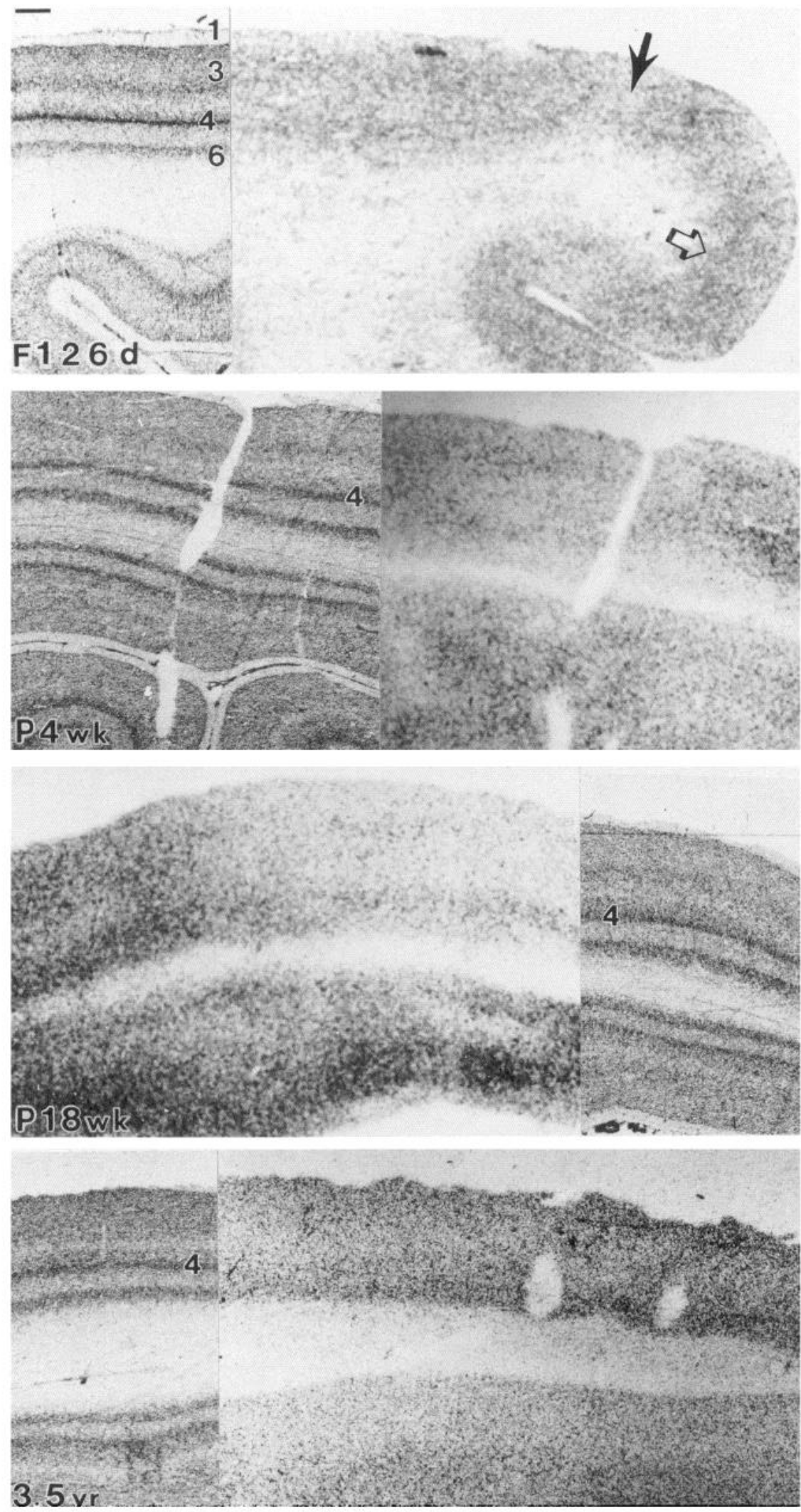

Figure 3. Autoradiographic distribution of $\mathrm{GABA}_{\mathrm{B}}$ receptors in Macaca nemestrina visual cortex. This plate shows sections of striate and prestriate cortex at F126d (top row), and striate cortex at P4wk (second row), P18wk (third row), and P3.5yr (bottom row) stained for cresyl violet or labeled for ${ }^{3} \mathrm{H}-\mathrm{BA}$ binding sites. The cresyl violet sections are aligned with the BA-labeled sections. Layer $4 \mathrm{C}$ is marked by 4 and layers 1,3 , and 6 are also marked in the panel from F126d. In the top row, the striate-prestriate border is marked by a solid arrow, and area 18, by an open arrow. In the postnatal ages, both cortical layers are striate. Frozen sections were cut from unfixed tissue, and these slide-mounted sections were incubated as described in Table 1. All photos are $10 \times$; scale bar in upper left corner equals $500 \mu \mathrm{m}$. columns were sectioned perpendicularly. This issue of "patchiness" is currently under study in blocks sectioned parallel with the cortical surface, a method that should optimize visualization o $\ldots$ ny possible difference in binding pattern that would correlate with the ocular dominance, color, and orientation module suborganization of primate striate cortex (reviewed in Hendrickson, 1985).

${ }^{3} \mathrm{H}$-BA binding for $\mathrm{GABA}_{\mathrm{B}}$ receptors shows light labeling 

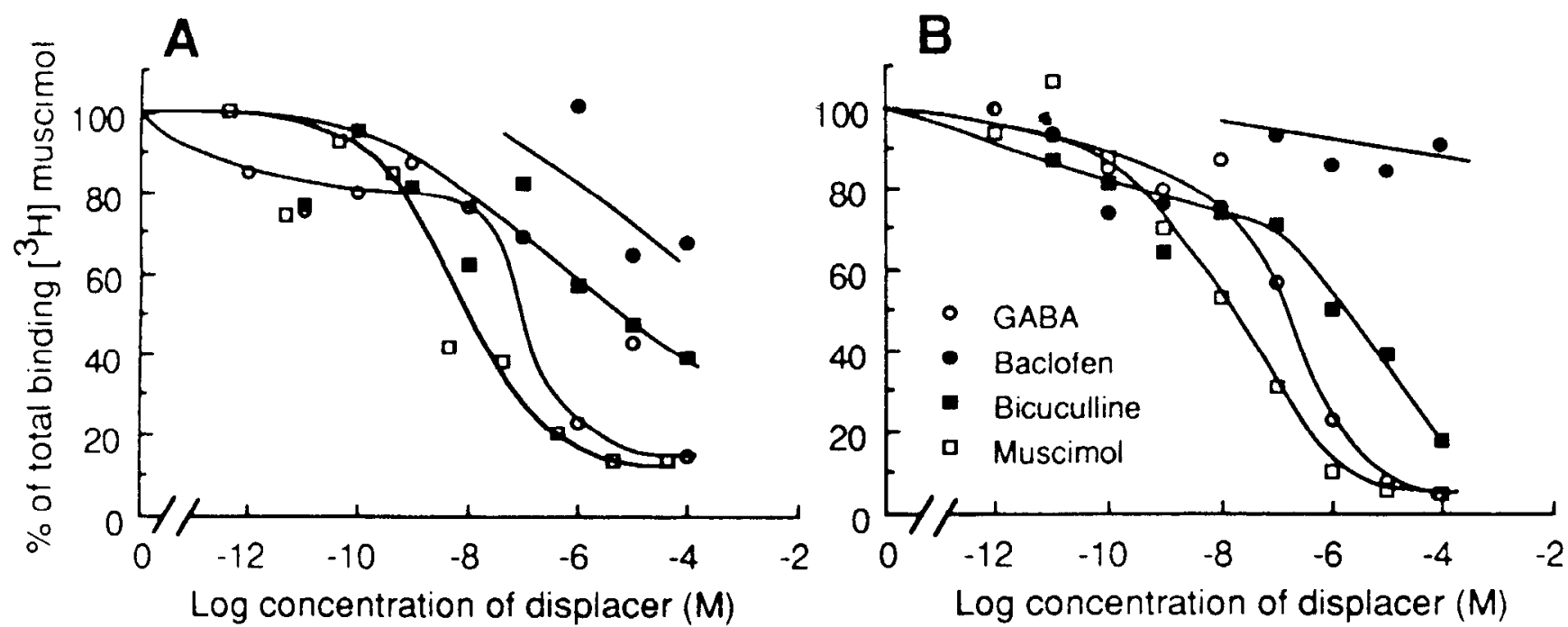

Figure 4. Characterization of the ${ }^{3} \mathrm{H}$-MS binding site in macaque striate cortex. Displacement of ${ }^{3} \mathrm{H}-\mathrm{MS}$ by other ligands in the F72d prenatal $(A)$ and P8.5yr adult $(B)$ monkey striate cortex is shown. All preincubation and incubation conditions are as described in Table 1, with a minimum of four sections used at each data point. Curves were fit by eye. Note that the relative potencies of the displacing ligands were similar in the two ages such that the $\mathrm{GABA}_{\mathrm{A}}$ agonists $\mathrm{MS}$ and GABA were more effective displacers of ${ }^{3} \mathrm{H}-\mathrm{MS}$ than the GABA antagonist bicuculline. The GABA $_{\mathrm{B}}$ agonist $B A$ was almost without effect.

throughout all layers in both striate and prestriate cortex from F126d onward (Fig. 3). With increasing age, a slightly lighter diffuse band appears in the middle of striate cortex that seems to overlap most or all of layer 4 and the overall density of BA binding shows a modest increase. Laminar labeling for BA is very diffuse compared to MS or FZ at all ages.

\section{Quantitative changes with age}

In order to establish that the binding sites labeled with ${ }^{3} \mathrm{H}-\mathrm{MS}$ are indeed $\mathrm{GABA}_{\mathrm{A}}$ receptors at the various ages, we have per- formed displacement experiments on visual cortex sections from the F72d (Fig. 4A) and the P8.5yr cortex (Fig. 4B) using the ligands GABA, MS, bicuculline methiodide, and BA. At both ages, the $\mathrm{GABA}_{\mathrm{A}}$ agonists GABA and $\mathrm{MS}$ and the $\mathrm{GABA}_{\mathrm{A}}$ antagonist bicuculline were effective displacers of $\mathrm{MS}$ binding, whereas BA, a GABA ${ }_{\mathrm{B}}$ agonist, had little effect. $\mathrm{IC}_{50}$ values for the F72d striate cortex were, in order of potency, MS > GABA $>$ bicuculline $\gg \mathrm{BA}$, and in the adult, were $\mathrm{MS}>\mathrm{GABA}>$ bicuculline $\gg \mathrm{BA}$. These data are consistent with the view that ${ }^{3} \mathrm{H}-\mathrm{MS}$ is selectively labeling a $\mathrm{GABA}_{\mathrm{A}}$ receptor population at

\section{Table 2. ${ }^{3} \mathrm{H}-\mathrm{MS}$ binding site characterization}

\begin{tabular}{|c|c|c|c|c|c|c|c|}
\hline \multirow[b]{2}{*}{ Age } & \multicolumn{3}{|c|}{$B_{\max }(\mathrm{fmol} / \mathrm{mg}$ protein $)$} & \multirow[b]{2}{*}{$\%$ Adult $^{b}$} & \multicolumn{3}{|c|}{ Affinity $\left(K_{d}\right.$ in $\left.\mathrm{nM}\right)$} \\
\hline & Low & High & Total $_{[\text {Total }}{ }^{a}$ & & Low & High & Single site fit \\
\hline F72d & $197 \pm 29$ & $108 \pm 18$ & $305[148]$ & $8 \%[4 \%]$ & $26 \pm 12$ & $4 \pm 1$ & $7 \pm 1$ \\
\hline F119d & $538 \pm 103$ & $164 \pm 2$ & $702[336]$ & $19 \%[10 \%]$ & $67 \pm 24$ & $7 \pm 0$ & $19 \pm 3$ \\
\hline F126d & $1046 \pm 118$ & $249 \pm 42$ & $1295[844]$ & $34 \%[24 \%]$ & $34 \pm 6$ & $4 \pm 1$ & $21 \pm 5$ \\
\hline F152d & $903 \pm 85$ & $602 \pm 25$ & $1505[765]$ & $40 \%[22 \%]$ & $62 \pm 17$ & $22 \pm 2$ & $31 \pm 4$ \\
\hline Pld & $1366 \pm 119$ & $183 \pm 19$ & $1549[1134]$ & $41 \%[33 \%]$ & $70 \pm 12$ & $7 \pm 1$ & $50 \pm 13$ \\
\hline P1.5d & $1825 \pm 58$ & $867 \pm 57$ & $2692[1324]$ & $71 \%[38 \%]$ & $100 \pm 7$ & $17 \pm 2$ & $30 \pm 5$ \\
\hline P4wk & - & $3011 \pm 411$ & - & $86 \%$ & - & $30 \pm 8$ & - \\
\hline P7wk & - & $3192 \pm 407$ & - & $92 \%$ & - & $43 \pm 8$ & - \\
\hline P18wk & - & $5869 \pm 723$ & - & $169 \%$ & - & $65 \pm 10$ & - \\
\hline P34wk & - & $4020 \pm 629$ & - & $116 \%$ & - & $53 \pm 10$ & - \\
\hline P36wk & - & $3948 \pm 646$ & - & $114 \%$ & - & $60 \pm 13$ & - \\
\hline P58wk & - & $2988 \pm 336$ & - & $86 \%$ & - & $26 \pm 5$ & - \\
\hline $\mathrm{P} 2.6 \mathrm{yr}$ & - & $785 \pm 125^{c}$ & - & - & - & $41 \pm 10$ & - \\
\hline $\mathrm{P} 3.3 \mathrm{yr}$ & - & $4865 \pm 503$ & - & $140 \%$ & - & $70 \pm 10$ & \\
\hline $\mathrm{P} 3.5 \mathrm{yr}$ & - & $5065 \pm 506$ & - & $146 \%$ & - & $38 \pm 5$ & \\
\hline $\mathrm{P} 8.5 \mathrm{yr}$ & - & $4079 \pm 273$ & & & & $30 \pm 3$ & \\
\hline P11.3yr & - & $2854 \pm 261$ & $\operatorname{avg} 346 /$ & $100 \%$ & & $49 \pm 6$ & \\
\hline
\end{tabular}

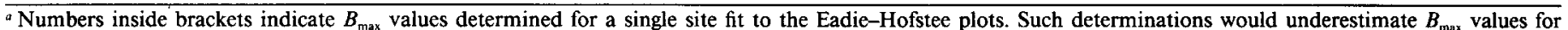
multiple binding sites.

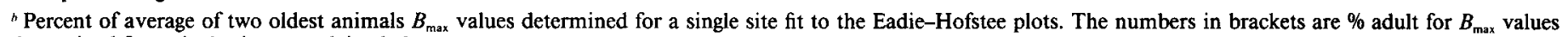
determined for a single site as explained above.

c Samples mistakenly included areas 17 and 18; not plotted in Figure 5. 
both ages and that the same pharmacologic receptor profile is present in fetal and adult cortex.

In Figure 5 and Table 2, we give the results of ${ }^{3} \mathrm{H}-\mathrm{MS}$ saturation binding assays to determine $\mathrm{GABA}_{\mathrm{A}}$ receptor number $\left(B_{\max }\right)$. Figure $5 A$ shows all developmental ages, and Figure $5 B$, up to P18wk only; specific numbers are given in Table 2 . At $\mathrm{F} 72 \mathrm{~d}, B_{\max }$ is at the lowest level of any age examined and is $8 \%$ of adult density, but less than $4 \%$ if a single site is assumed. $B_{\max }$ values increase steadily to an average of $56 \%(35 \%$ for a single site) of adult at P1d-1.5d and $86 \%$ at P4wk and reach an apparent peak at P18wk of $169 \%$ adult density. Values then decrease to 1 year $(86 \%)$, rise again in the juvenile animals to an average of $143 \%$, and finally decline to adult levels by P8.5yr or later. Thus $\mathrm{GABA}_{\mathrm{A}} B_{\max }$ has a bimodal developmental sequence. The close agreement of paired age animals supports that this is not due to individual variation.

In Figure 6, we show Eadie-Hofstee plots of saturation binding experiments to determine $\mathrm{GABA}_{\mathrm{A}}$ receptor affinity $\left(K_{d}\right)$ at F126d and P8.5yr. In the adult (Fig. 6A), the resulting graph shows a straight line with a $K_{d}$ of $30 \mathrm{~nm}$ and a correlation coefficient of 0.96 , but at F126d (Fig. $6 B$ ), the Eadie-Hofstee plot has a curvilinear shape with a correlation coefficient of 0.67 , suggesting multiple sites. A curvilinear Eadie-Hofstee plot is not in itself indicative of multiple binding sites because poorquality data, as well as multiple binding sites, will give large $\mathrm{SD}$ (erad) (SD of background error) values (Zivin and Waud, 1982). In such instances, Hill plots, as well as the use of a "limiting slopes" technique (Hunston, 1975), increase confidence that such curvilinear plots do comprise multiple binding sites. A Hill plot of the adult data (Fig. 6C) gives a coefficient of 1.03 , indicating a single binding site. At F126d (Fig. 6D), the data have a Hill coefficient of greater than 1.42, and multiple site analysis reveals the presence of two binding sites, with $K_{d}$ values of 34 nм and 4 nм. Data from F72d, F119d, F152d, and P1d also show two binding sites, but older animals all show a single binding site (Table 2). In Figure $6 E, \mathrm{GABA}_{\mathrm{A}}$ receptor $K_{d}$ is plotted using a best fit to a single binding site for all ages. $K_{d}$ values peaked at P18wk, declined to P58wk, and then remained relatively constant into adulthood. One female at P3.3yr showed a high $K_{d}$ value compared to all other postnatal animals. The $\mathrm{SD}(\mathrm{erad})$ value for this animal was acceptable, and the reason for this discrepant point is not clear. Affinity changes associated with the estrous cycle have bcen reported (Van Huizen et al., 1988), and this monkey would have been at or near the onset of puberty in our colony (G. Ruppenthal, personal communication). With the exception of this one point, the curve in Figure $6 E$ is in good agreement with the development profile for receptor number (Fig. $5 A$ ). The affinity changes over the entire developmental period are of a smaller magnitude than the corresponding $B_{\max }$ changes. The presence of multiple binding sites before birth would raise the number of receptors at these ages (see Table 2), so the points are likely to be the minimum prenatal values for the number of $\mathrm{GABA}_{\mathrm{A}}$ receptors. Our data indicate a shift near birth from multiple to single binding sites in the $\mathrm{GABA}_{\mathrm{A}}$ receptor population, as well as a striking increase in receptor number at the same age.

Due to scarcity of tissue, benzodiazepine receptors were studied using ${ }^{3} \mathrm{H}-\mathrm{FZ}$ binding at selected ages only. The resulting $B_{\max }$ values are $\mathrm{F} 126 \mathrm{~d}=254 \pm 16, \mathrm{P} 1.5 \mathrm{~d}=1067 \pm 60, \mathrm{P} 18 \mathrm{wk}=$ $701 \pm 58$, and $\mathrm{P} 8.5 \mathrm{yr}=946 \pm 133 . K_{d}$ values are $\mathrm{F} 126 \mathrm{~d}=2.9$ $\pm 0.8 \mathrm{nM}, \mathrm{P} 1.5 \mathrm{~d}=1.8 \pm 0.2 \mathrm{nM}, \mathrm{P} 18 \mathrm{wk}=2.3 \pm 0.2 \mathrm{nM}, \mathrm{P} 8.5 \mathrm{yr}$ $=5.4 \pm 1.1 \mathrm{nM}$, with only a single site detected at each age.
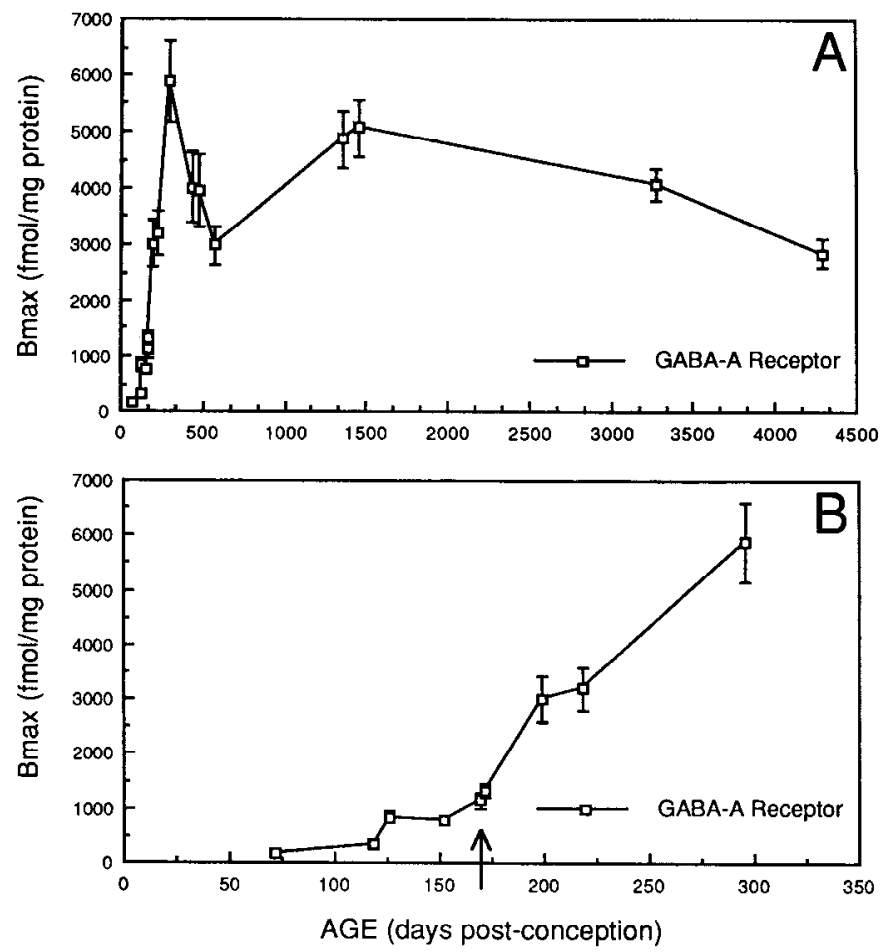

Figure 5. $B_{\max }$ determination for $\mathrm{GABA}_{\mathrm{A}}$ receptors in macaque striate cortex during development. The number of GABA $A_{A}$ receptors $\left(B_{\max }\right)$ labeled with ${ }^{3} \mathrm{H}$-MS was determined from scraped sections by saturation binding assays (see Materials and Methods) and expressed as $\mathrm{fmol} / \mathrm{mg}$ protein. Section assays were carried out as described in Table 1, and the resulting data were analyzed using Eadie-Hofstee plots as described in Zivin and Waud (1982). In all cases, SD(erad) values were very good to acceptable, ranging from 0.07 to 0.16 . In $A, B_{\max }$ values for $\mathrm{F} 72 \mathrm{~d}$ to P11.3yr are plotted. In $B$, the ages up to P18wk are shown on an expanded time scale. Birth is indicated by an arrow in $B$. In both graphs, error bars indicate SEM for values determined in one individual experiment only. Note the good agreement between animals at similar ages. The lines were fit by eye, although the quantitative detcrmination of $B_{\max }$ and $K_{d}$ values were obtained from the LIGAND binding program used to generate Eadie-Hofstee plots, which some authors consider to be more accurate, with $B_{\max }$ being determined by the y-axis intercept (Zivin and Waud, 1982). In ages with apparent multiple binding sites, we felt confident enough both in the range and number of concentrations and in the quality of the resulting data to attempt a "limiting slopes" method for calculating $B_{\max }$ and $K_{d}$ values separately for each of two binding sites (see Hunston, 1975; Bylund, 1980). Such separately determined $B_{\max }$ and $K_{d}$ values had SD(erad) values below 0.2 , thus satisfying the criteria of Zivin and Waud (1982) for acceptable error.

Figure 7 shows a comparison of $B_{\max }$ values for ${ }^{3} \mathrm{H}-\mathrm{FZ}$ and ${ }^{3} \mathrm{H}$-MS binding at the selected ages for which both were determined. First, note that at all ages the absolute $B_{\max }$ value is at least three times higher for the $\mathrm{GABA}_{\mathrm{A}}$ receptor (left ordinate) compared to the benzodiazepine receptor (right ordinate). Second, the two $B_{\max }$ values have different developmental profiles. There is a large prenatal increase in the benzodiazepine receptor from $27 \%$ of adult values at $F 126$ d to $74 \%$ at $P 1.5$ d, relative to a much smaller increase in the $\mathrm{GABA}_{\mathrm{A}}$ receptor from $21 \%$ versus $33 \%$ over the same period. In contrast, although postnatal ${ }^{3} \mathrm{H}-$ FZ binding increases by P18wk to $113 \%$ of adult value, this increase is less than the $144 \%$ postnatal increase for ${ }^{3} \mathrm{H}-\mathrm{MS}$ binding. Third, the $B_{\max }$ ratio of $\mathrm{GABA}_{\mathrm{A}}$ to benzodiazepine is not constant with age. At F126d, it is $1: 3$ and drops to $1: 2$ at birth, but then the ratio rises to $1: 6$ at $P 18 \mathrm{wk}$ and levels out at 1:4 in the adult. This suggests that MS and FZ binding sites are 

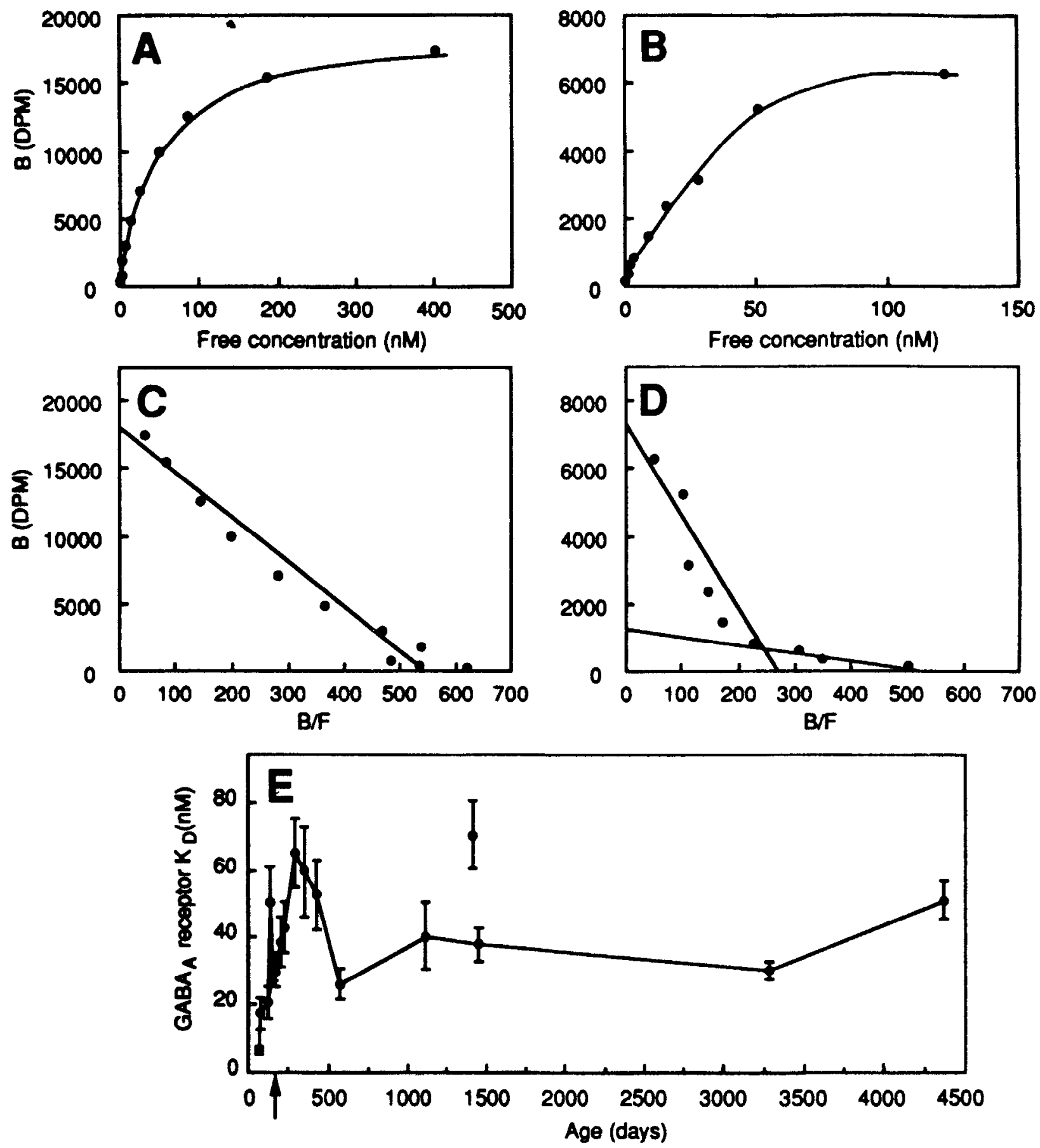

Figure 6. $K_{d}$ determinations for $\mathrm{GABA}_{\mathrm{A}}$ receptors in macaque striate cortex during development. Saturation binding assay for ${ }^{3} \mathrm{H}-\mathrm{MS}$ done as in Table 1 in the P8.5yr $(A)$ and $\mathrm{F} 126 \mathrm{~d}(B)$ visual cortex, plotting specific binding in dpm versus free concentration of ${ }^{3} \mathrm{H}$-MS. In $C$ and $D$, these data are replotted using Eadie-Hofstee methods. In the adult $(C)$, the best fit of these data is a straight line, indicating a single ${ }^{3} \mathrm{H}-\mathrm{MS}$ binding site. The F126d data $(D)$ shows a curvilinear shape, which is best fit by two straight lines, indicating the presence of a high-and a low-affinity binding site. $E, K_{d}$ values plotted as a function of days postconception. For each animal, the best fit for a single binding site was made (see Materials and Methods). Error bars indicate individual experiment SEM based on multiple data points. Birth is marked by an arrow in $E$.

differentially altered during development. These ratio changes further suggest that the two $\mathrm{GABA}_{\mathrm{A}}$ receptor components are not always linked in the same ratio and may not even share the same neuronal sites.

The percentage of nonspecific to total binding at all ages was low for both ligands. For ${ }^{3} \mathrm{H}-\mathrm{MS}$, the highest nonspecific binding of $26 \%$ was found at $F 72 \mathrm{~d}$ and was only $8 \%$ in the adult. Con- versely, ${ }^{3} \mathrm{H}-\mathrm{FZ}$ nonspecific binding was $2 \%$ at $\mathrm{F} 126 \mathrm{~d}$, increased to $11 \%$ at $\mathrm{P} 18 \mathrm{wk}$, and was $17 \%$ in the adult. This relatively low level at all ages justifies our conclusions of high specific binding during development, and supports the qualitative autoradiographic film pictures discussed earlier.

Quantitative densitometric analysis of layers $4 \mathrm{C}$ and $2 / 3$ from films at F126d to adult gave a slightly more complex picture of 

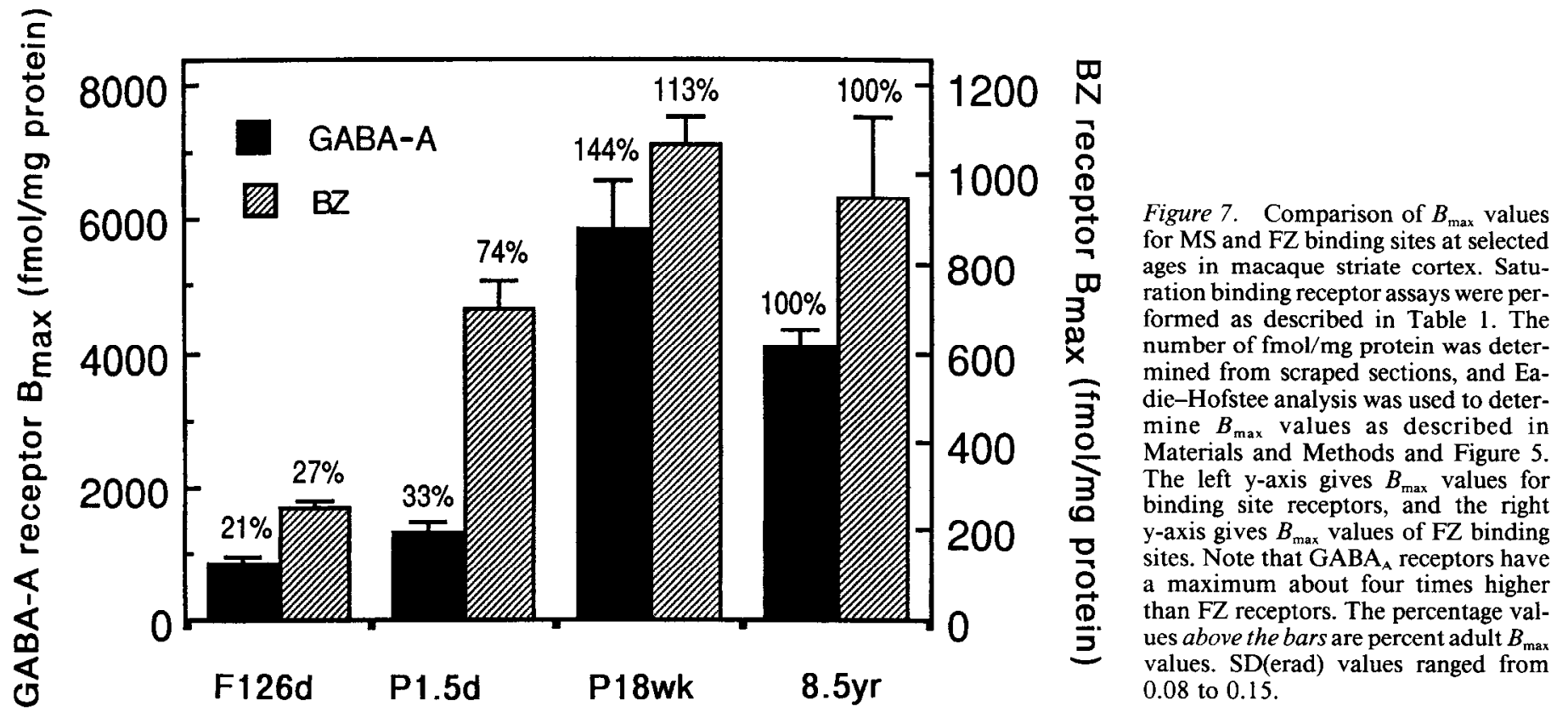

$\mathrm{GABA}_{\mathrm{A}}$ receptor devclopment. The absolute values are given in Table 3, and the percent highest value for each layer is plotted in Figure 8. MS binding sites are quite sparse before birth, but layer $4 \mathrm{C}$ still is $30 \%$ higher than the upper cortical layers. Overall, MS binding values increase after birth, but layer $4 \mathrm{C}$ always has the highest concentration, although the difference is small at P49d and P18wk. When MS binding site density is plotted as a percentage of its highest value for each layer (Fig. $8 \mathrm{~A}$ ), it can be seen that layer $2 / 3$ actually overshoots layer $4 \mathrm{C}$ after birth and then declines somewhat by adulthood. The MS binding site density in layer $4 \mathrm{C}$ continues to rise steadily after birth to adulthood. FZ binding site density shows relatively little difference between layers $4 \mathrm{C}$ and $2 / 3$ before birth, and then a larger separation appears at $\mathrm{P} 49 \mathrm{~d}$ and $\mathrm{P} 18 \mathrm{wk}$ when layer $4 \mathrm{C}$ has twice the density of layer $2 / 3$. When $F Z$ laminar density is plotted for percentage of its highest value (Fig. $8 B$ ), layer $4 \mathrm{C}$ actually peaks at $\mathrm{P} 49 \mathrm{~d}$ and then declines sharply to P58wk. Layer $2 / 3$ rises steadily after birth to $P 18$ wk and changes little thereafter. In Figure $8 C$, we plot the ratios of $\mathrm{MS}$ and $\mathrm{FZ}$ binding site density in layers $2 / 3$ compared to layer $4 \mathrm{C}$. Notice that the two ligands show opposite patterns in that just after birth, MS binding is relatively enriched in the upper layers while layer 4 is relatively enriched for $\mathrm{FZ}$ binding. In older animals, the opposite relationship was found.

\section{Discussion}

There are several notable results in this study of the development of $\mathrm{GABA}_{\mathrm{A}}$ and $\mathrm{GABA}_{\mathrm{B}}$ receptors in monkey visual cortex: (1) Significant levels of MS and FZ binding sites are found at F61d-72d, more than 3 months before birth. (2) There is a direct correlation between prenatal age and number of MS binding sites. The youngest cortex had the lowest number, followed by a stcady increase up to birth, a rapid increase in the 4 months after birth, and a long decline into adulthood. (3) FZ binding site number is relatively high before birth, shows a small increase in the 4 months after birth, but declines relatively little into adulthood. (4) These two patterns are reflected in a ratio of FZ to MS binding site number, which is $1: 2-3$ before birth but rises to 1:4-6 after birth. (5) Laminar patterns for the two ligands differ during development. MS density in layer $4 \mathrm{C}$ increases up to $\mathrm{P} 13 \mathrm{mo}$ but plateaus in layer $2 / 3$ by $\mathrm{P} 18 \mathrm{wk}$. FZ density in layer $4 C$ drops sharply after $P 49 d$, while layer $2 / 3$ remains high into adulthood. (6) $\mathrm{GABA}_{\mathrm{B}}$ binding was present before birth in all layers and showed little change with age for either density or laminar distribution.

An unexpected result in this study is the presence of significant levels of both MS and FZ binding sites in the cortical plate early in development. Our saturation binding analysis has shown that at F72d, binding site number is $\mathbf{4 - 8 \%}$ of adult levels. Many cortical plate neurons also are immunocytochemically stained for GABA by F60d-72d (Hendrickson et al., 1988; Meinicke and Rakic, 1989). In contrast, at F72d synaptic contacts are

Table 3. Densitometry of laminar receptor binding

\begin{tabular}{|c|c|c|c|c|}
\hline \multirow[b]{3}{*}{ Age } & \multirow{2}{*}{\multicolumn{2}{|c|}{${ }^{3} \mathrm{H}-\mathrm{MS}$}} & \multicolumn{2}{|l|}{${ }^{3} \mathrm{H}-\mathrm{FZ}$} \\
\hline & & & \multirow[b]{2}{*}{ Layer $4 \mathrm{C}$} & \multirow{2}{*}{$\begin{array}{l}\text { Layer } \\
2 / 3^{a}\end{array}$} \\
\hline & Layer $4 \mathrm{C}$ & Layer $2 / 3^{a}$ & & \\
\hline F126d & 0.9 & 0.6 & - & - \\
\hline F152d & 2.6 & 1.6 & 6.2 & 5.8 \\
\hline $\mathrm{P} 1.5 \mathrm{~d}$ & 8.2 & 5.1 & 9.5 & 9.1 \\
\hline P4wk & 14.4 & 11.2 & 12.3 & 10.2 \\
\hline P7wk & 13.5 & 11.9 & 25.3 & 12.4 \\
\hline P18wk & 15.8 & 13.9 & 23.1 & 14.3 \\
\hline P58wk & 19 & 13.8 & 15.8 & 14.5 \\
\hline $\mathrm{P} 3.5 \mathrm{yr}$ & 19 & 12.4 & 19 & 15.9 \\
\hline
\end{tabular}

Pcak densities for receptor binding in the different layers were determined by calibration to measured film values of Amersham ${ }^{3} \mathrm{H}$-Microscales in the range of actual polymer activity $\left(\mathrm{nCi} / \mathrm{mg}\right.$ ) from 3.03 to $109.08 \mathrm{nCi} / \mathrm{mg}$. Because $K_{d}$ values are age dependent and the measured density values were determined from film autoradiograms of binding experiments using a single concentration of radioligand, these values do not necessarily represent receptor $B_{\max }$ for that layer at each age. Further, from the values given in the table, it is not possible to compare actual receptor density for MS versus $\mathrm{FZ}$ binding sites since the values given are in relative units. For overall $B_{\text {max }}$ values see Figures 5 and 7 and Table 2 .

a Measurements for layers $2 / 3$ include a variable amount of layer $4 \mathrm{~A}$ that could not be separated in the films from layer 3 . 

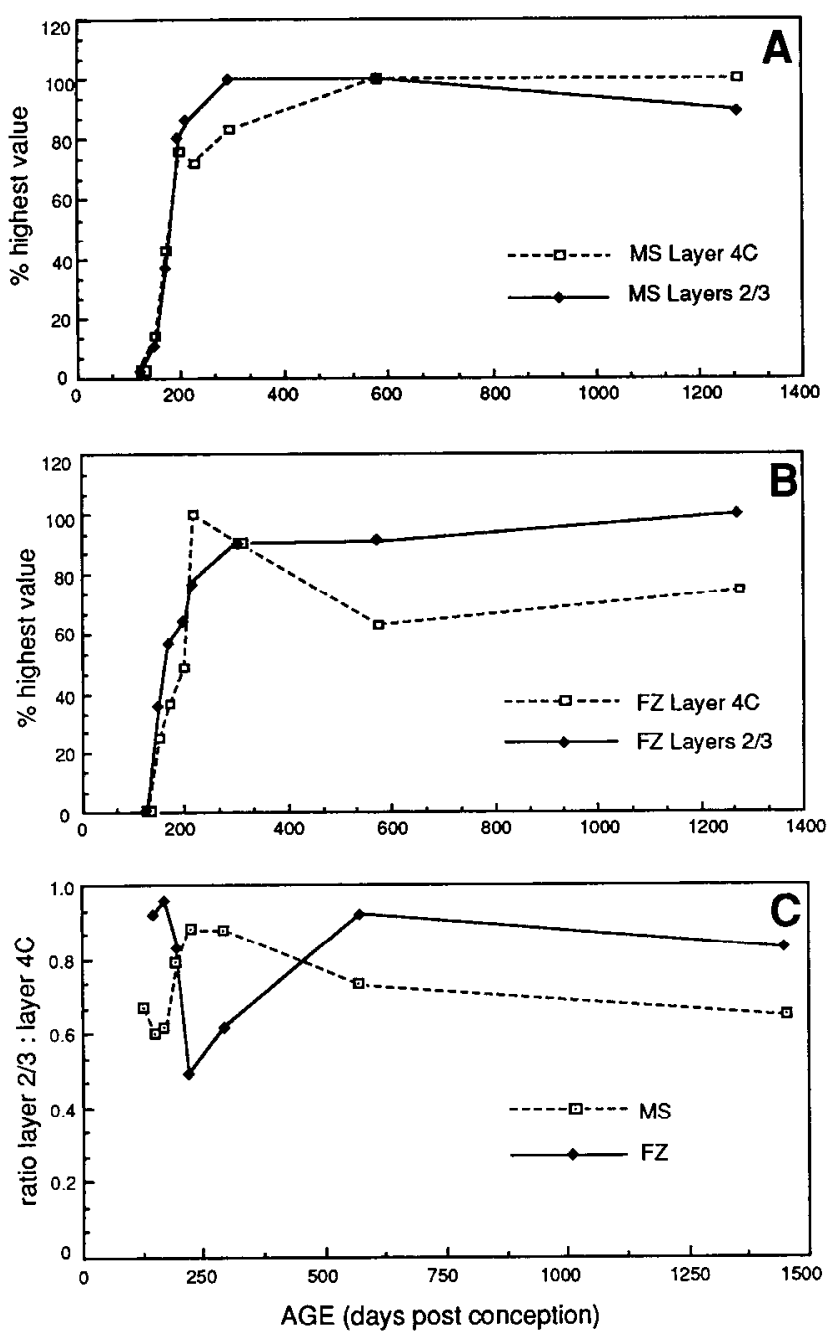

Figure 8 . Plots of the change in binding site density with age in layer $4 \mathrm{C}$ and layers $2 / 3$ of macaque striate cortex for ${ }^{3} \mathrm{H}-M S(A)$ and ${ }^{3} \mathrm{H}-F Z$ $(B)$. Binding site density was determined from autoradiograms films using an Imaging Research Inc. system (see Materials and Methods and values in Table 3 ). The percent highest value in layer $4 \mathrm{C}$ and layers $2 / 3$ is plotted for each age analyzed. $C$, The density in layers $2 / 3$ is compared to density in layer $4 \mathrm{C}$, and this ratio is plotted for $M S$ and $F Z$. Age is given in days postconception (approximately 165-170 d).

virtually absent from the cortical plate, although a very few are found in the marginal zone and subplate (Rakic et al., 1986; Zielinski and Hendrickson, 1990). By F72d, the axons from the dorsal lateral geniculate nucleus have reached the deep intermediate zone but still have not penetrated the cortex in any numbers (Rakic, 1977). Thus, both the MS and FZ binding sites of the $\mathrm{GABA}_{\mathrm{A}}$ receptor and GABAergic neurons are clearly present well-before most synaptic development begins in either intrinsic or thalamic axon systems. Film-based, receptor-binding autoradiography does not allow cellular resolution, so light microscopic and EM immunocytochemical methods currently are being applied to identify exactly where these early $\mathrm{GABA}_{\mathrm{A}}$ receptors are located.

Although both $\mathrm{FZ}$ and MS labeling are coincident with the cortical plate, FZ binding sites are also present over the subplate/ intermediate zone and in high amounts over the marginal zone in early prenatal cortex. As well, overall $\mathrm{FZ}$ binding site numbers are relatively high prenatally compared to MS binding site num- bers. One explanation of this discrepancy is that benzodiazepine receptors may exist that are not coupled to $\mathrm{GABA}_{\mathrm{A}}$ receptors (Unnerstall et al., 1981; Richards and Mohler, 1984; Shaw et al., 1987). However, recent molecular biology analysis of the $\mathrm{GABA}_{\mathrm{A}}$ receptor has revealed an unexpected structural complexity in that it is composed of four types of subunits, each subunit has several different forms, and the subunits can occur in different combinations (Kuman et al., 1987; Sieghart, 1989; Malherbe et al., 1990; Olsen and Tobin, 1990). In immature rodent cortex, protein gels and immunoprecipitation studies indicate several different but closely related proteins are found that bind ${ }^{3} \mathrm{H}-\mathrm{FZ}$, while in the adult only a single protein is found (Eichinger and Sieghart, 1986; Sato and Neale, 1989a,b; Vitorica et al., 1990). Moreover, electrophysiological recording of cortical slices in vitro has found that most $\mathrm{GABA}_{\mathrm{A}}$ receptors mediate depolarization in neonatal rat cortex, but this changes to a preponderance of hyperpolarization responses as the cortex matures (Kricgstcin ct al., 1987; McCormick and Prince, 1987; Scharfman and Sarvey, 1987; Luhmann and Prince, 1991). Thus, during development there may be a shift in the subunit type and composition of the $\mathrm{GABA}_{\mathrm{A}}$ receptor, giving rise to different receptor characteristics that may modify not only $F Z$ and $M S$ binding, but $\mathrm{GABA}_{\mathrm{A}}$ receptor function as well. Our results in monkey are in keeping with this view, showing the existence of at least two different ${ }^{3} \mathrm{H}$-MS binding sites early in development, but only one after birth. There is also an age-related change in affinity in monkey cortex, with the lowest affinity (highest $K_{d}$ ) coincident with the highest number of MS binding sites at P18wk. These changes are similar to $\mathrm{GABA}_{\mathrm{A}}$ receptor affinity/number changes in cat visual cortex during postnatal development (Shaw et al., 1984, 1987). Although our quantitative analysis of FZ binding sites did not include all prenatal ages because of the scarcity of tissue, our $K_{d}$ values suggest a decrease in affinity with agc, also similar to cat visual cortcx (Shaw ct al., 1987). Thus, monkey striate cortex $\mathrm{GABA}_{\mathrm{A}}$ receptors go through a stage shortly after birth in which a larger number of receptors exist that bind GABA relatively easily at low concentration (low affinity). With age the number of receptors decreases and the specificity of binding increases; both changes suggest that maturation involves the emergence of highly selective GABA binding at developmentally selected postsynaptic sites.

How does our monkey data compare with GABA receptor development in other species? Several problems arise when attempting such a cross-species comparison. The first is the difficulty of correcting for differing gestation lengths and maturity at birth. Rat cortical development at birth is equal to that of human at embryonic (E) $20 \mathrm{wk}$, which is $50 \%$ of human gestation (Kellogg, 1988). This allows an equivalent prenatal scale to be constructed to correct for different lengths of gestation and different degrees of maturity at birth in rat, monkey, and human, if we assume that monkey and human cortical development is equal at birth (Boothe et al., 1985; Boothe, 1988). In the following discussion, we have made these calculations and the percentages given are for "corrected gestation." Second, many studies use whole brain, rather than cerebral cortex, and of those using cortex, few sample only visual cortex. Given the very different rates of regional development within the brain and the known regional receptor heterogeneity, this limits direct numerical comparisons. Finally, few laboratories have studied more than one receptor, or more than one species, so interlaboratory variability in methods can be a problem. Given these limitations, we can point out the following comparisons of our monkey 
developmental data for MS and FZ binding sites with that available from rat, cat, and human studies.

FZ binding sites detected by ligand binding appear at similar prenatal ages; in rat frontal cortex at $32 \%$ of gestation (Schlumpf et al., 1983), in human at 37\% (Aaltonen et al., 1983), and in this study at $37 \%$, both FZ and MS binding sites are present in monkey visual cortex. The first GABAergic neurons are found in marginal and subplate/intermediate zones of rat frontal cortex at $32 \%$ of gestation and in cortical plate at $36 \%$ (Lauder et al., 1986; Van Eden et al., 1989). Numerous GABA+ cells are present in all these areas by F61d in monkey (Hendrickson et al., 1988; Meinicke and Rakic, 1989), which is $37 \%$ of gestation. Although monkey fetuses need to be examined at even earlier ages, these data in both rat and monkey suggest that GABAergic neurons appear about the same time as $\mathrm{GABA}_{\mathrm{A}}$ receptors. GA$\mathrm{BA}_{\mathrm{A}}$ receptors detected immunocytochemically by one antiserum do not appear until $75 \%$ of gestation in monkey visual cortex (Meinicke and Rakic, 1989) or at $71 \%$ in somatosensory cortex using another antiserum (Huntley et al., 1990). The reason for this late immunocytochemical appearance is not clear and needs to be examined with other antisera to the wide variety of GABA ${ }_{A}$ receptor subunits that have been recently discovered (reviewed by Kuman et al., 1987; Sieghart, 1989; Malherbe et al., 1990; Olsen and Tobin, 1990).

Synaptic development occurs much later than $\mathrm{GABA}_{\mathrm{A}}$ receptor appearance in both rat and monkey. At $44 \%$ gestation in monkey, synaptic density in striate cortex is almost nil (Rakic et al., 1986; Zielinski and Hendrickson, 1990). Even at 68\% gestation, the upper cortical layers have few synapses but are well endowed with FZ binding sites and, to a lesser degree, with MS binding sites (see below). In rat occipital cortex, synaptogenesis does not begin until after birth (Blue and Parnavalas, 1983) but both FZ and MS binding sites are detectable well before birth (Coyle and Enna, 1976; Braestrup and Nielsen, 1978), although Schlumpf et al. (1983) point out that the cortical plate does not contain FZ binding sites until F21. E16d rat cortical neurons cultured in vitro have functional $\mathrm{GABA}_{\mathrm{A}}$ receptors in the total absence of synapses (Köller et al., 1990), and it is interesting that in this in vitro system $\mathrm{GABA}_{\mathrm{A}}$ receptors appear $4 \mathrm{~d}$ earlier than the first functional glutamate receptors. Human cortex has $6 \%$ of adult FZ labeling by $38 \%$ gestation (Aaltonen et al., 1983), well before synapses are described (Boothe, 1988). Thus, both rats and primates show similar developmental sequences, with $\mathrm{GABA}_{\mathrm{A}}$ receptors appearing earlier than morphological synapses.

Our monkey data show a rapid postnatal increase of $\mathrm{GABA}_{\mathrm{A}}$ receptors to a peak around $\mathrm{P} 18 \mathrm{wk}$, which is particularly clear for MS binding sites but also is true to a lesser degree for FZ binding sites. Both eventually decline by adulthood. In rat brain, FZ binding sites reach $35-50 \%$ of adult levels by birth and adult levels by P4wk-5wk (Braestrup and Nielsen, 1978; Palacios et al., 1979; Aldinio et al., 1981). The only rat study to compare FZ and MS binding directly (Palacios et al., 1979) found that MS levels are less than $10 \%$ of adult at birth, which is significantly lower than FZ levels. MS binding then shows a rapid postnatal rise to also reach adult levels by $\mathrm{P} 4 \mathrm{wk}$. Aldinio et al. (1981) and Eichinger and Sieghart (1986) also find a postnatal decline for FZ binding in rat; Aldinio et al. (1981) report a peak at P35d followed by a $15 \%$ decrease to P12wk, while the latter authors find a peak at $\mathrm{P} 22 \mathrm{~d}$ and a similar decline. Most rodent studies utilize P4wk-6wk animals as "adult," so it is possible that the failure to extend the age range may have caused others to miss a postnatal peak and subsequent decline. The cat visual cortex is quite immature at birth and is more similar to rat than to monkey in this regard. At P3d in cat striate cortex, FZ binding levels are 27\% (Shaw et al., 1987) and MS 59\% (Shaw et al., 1984) of adult. FZ binding site numbers peak at P8wk, and MS binding site numbers peak at P14wk, followed by a decline of about $30 \%$ to adulthood for both. Human frontal cortex has $47 \%$ of adult MS binding and $22 \%$ of adult FZ binding near birth (Brooksbank et al., 1981, 1982), with no postnatal decline noted. The Brooksbank et al. perinatal group was composed of premature plus full-term infants, and given the rapid rise in both MS and FZ labeling that we found in monkeys in the latter part of gestation, mixing these critical ages could lower their final number and mask a peak. Thus, monkeys, cats, and perhaps rats show a postnatal peak followed by a decline in one or both $\mathrm{GABA}_{\mathrm{A}}$ receptor binding sites.

Is there any correlation with synaptic density changes and $\mathrm{GABA}_{\mathrm{A}}$ reccptor number in monkey striate cortex? To test this, we plotted synaptic density data from Zielinski and Hendrickson (1990) against our $B_{\max }$ data for MS binding sites (Fig. 9A). Both curves show a similar overall shape, a peak density around 3 months, and a long decline. In early development (Fig. 9B), MS binding site numbers lead synaptic density, as would be predicted from the species comparisons discussed above. By F126d in macaque striate cortex, all neurons are in place, all of the layers can be recognized, and LGN axons are present in layer 4 (Rakic, 1977). Synapses are found in all layers, although still at a relatively low density of $15 \%$ adult levels. By F152d, ocular dominance columns are beginning to appear (Rakic, 1977), and many synapses are found in all layers of cortex with a density of $64 \%$ of adult. MS binding site numbers now lag behind synaptic density, being only $22 \%$ of adult levels. After birth, both synaptic density and MS binding site numbers rise very rapidly to an apparent peak of $160 \%$ adult at P12wk for synaptic density and $169 \%$ adult at P18wk for MS binding site number. Both decline to reach approximate adult levels by $\mathrm{P} 1 \mathrm{yr}-2 \mathrm{yr}$, although MS binding site number shows a second late peak around P3.5yr. This time point was not included in our study, but the data of Rakic et al. (1986) do not show a second peak at this time for synaptic development.

Although the correlation in shape and peak density between MS binding sites and synaptic density is intriguing, this should be treated with caution. Because GABAergic synapses are no more than $25 \%$ of the total average density (V. LaVie and A. Hendrickson, unpublished observations), they may have a different developmental profile that is masked by the larger number of asymmetric contacts. On the basis of morphological criteria, Zecevic et al. (1989) found that symmetric contacts, presumably GABAergic, constitute a relatively constant $<10 \%$ throughout monkey motor cortex development and do not show either a peak after birth or a massive decline postnatally. If true for monkey striate cortex, this would mean that there is little correlation between GABAergic synaptic number and receptor number. On the other hand, Blue and Parnavalas (1983) found a dramatic postnatal increase in symmetric contacts in rat striate cortex followed by a marked decline between P20d-90d. This is similar to our overall synaptic density curve and the rat cortex FZ and MS binding studies discussed earlier (Braestrup and Nielson, 1978; Palacios et al., 1979; Aldinio et al., 1981; Eichinger and Sieghart, 1986). We have found that EM morphological criteria fail to differentiate asymmetric from symmetric synapses in more than $80 \%$ of prenatal synaptic contacts (Zie- 

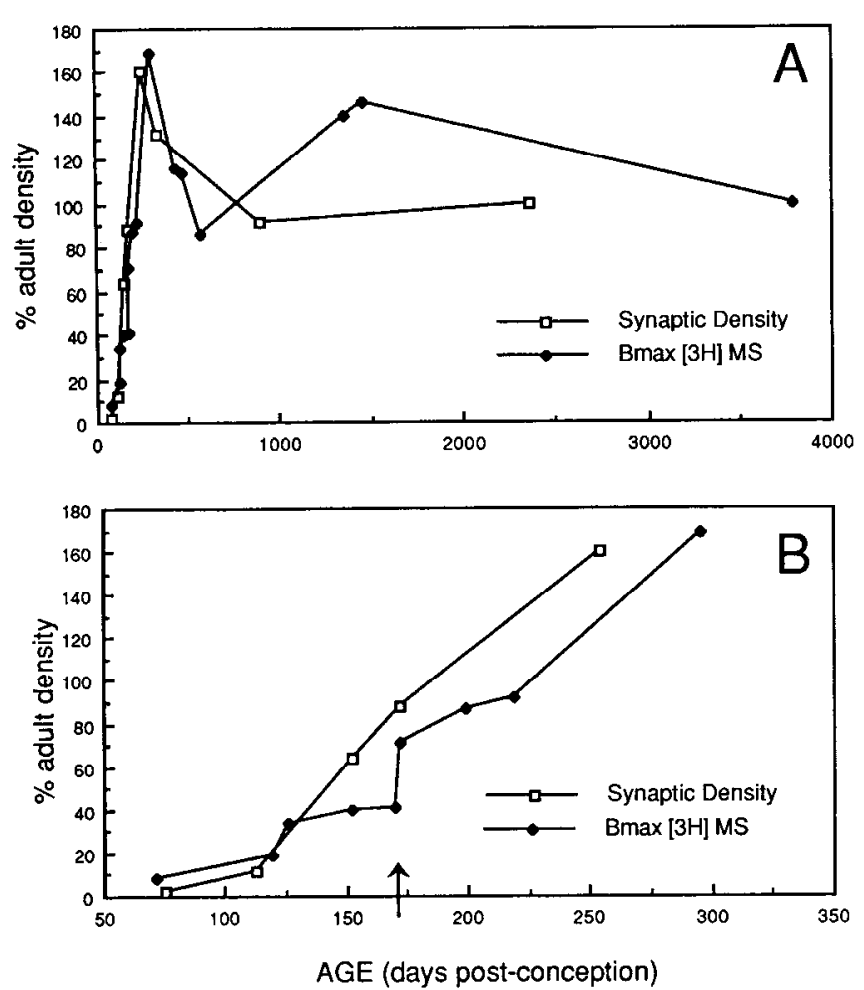

Figure 9. A comparison of age-related changes between the number of ${ }^{3} \mathrm{H}-\mathrm{MS}$ binding sites and the average synaptic density in macaque striate cortex. Each point represents one animal whose receptor number $\left(B_{\max }{ }^{3} \mathrm{H}\right.$-MS) or synaptic density averaged for all cortical layers was determined. Values are plotted as percentages of adult values. For synaptic counts, all animals were perfused with $4 \%$ paraformaldehyde, $0.05 \%$ glutaraldchyde, $0.2 \%$ picric acid in $0.1 \mathrm{~m}$ phosphate buffer, $\mathrm{pH}$ 7.3. Blocks of opercular striate cortex over the calcarine sulcus were postfixed in $2 \%$ osmium tetroxide and embedded in plastic. Thin sections were cut that included all layers of the cortical plate or cortex, and EM photographic montages were made at a final magnification of $24,000 \times$. Synapses (defined as three or more vesicles in the presynaptic process opposite an obvious postsynaptic density) were counted and the amount of neuropil determined using a grid overlay in every other photograph of the montage. Synaptic density is expressed as synapses/ $100 \mu \mathrm{m}^{2}$ neuropil. $A$ covers the entire age range from $F 72 \mathrm{~d}$ to adult, and $B$ is an expanded view of F72d to P18wk (birth is marked by an arrow).

linski and Hendrickson, 1990), and so studies using EM immunogold to label GABA synapses are currently under way to detect directly this population and allow more accurate counts of its development in monkey visual cortex.

What might be the role for GABAergic nonsynaptic interactions early in development? One possibility is that GABA and its receptors may serve a mitogenic or growth-related role in early neural development (reviewed in Spoerri, 1987; Wolff et al., 1987; Lauder, 1988; Belhage et al., 1990). These studies have shown that neurons in vivo and in vitro respond to the application of GABA by enhanced neurite outgrowth and branching, accelerated organelle development, synaptogenesis, or increased protein synthesis. In some of these studies, this action is blocked by the $\mathrm{GABA}_{\mathrm{A}}$ antagonist bicuculline, indicating that the transmitter/receptor interactions are involved. Recently, it has been shown in adult monkey cerebellum that both MS and FZ binding sites as detected by subunit specific antibodies are found on membrane surfaces of postsynaptic cell bodies and dendrites, as well as at symmetric synaptic contacts (Somogyi, 1989; Somogyi et al., 1989). This suggests that GABA acting via $\mathrm{GABA}_{\mathrm{A}}$ receptors may subserve a modulatory role in addition to neurotransmission, even in adult neurons. Another possibility is that $\mathrm{GABA}_{\mathrm{A}}$ receptors may serve as targets for incoming axons, particularly because some growth cones release GABA (Gordon-Weeks et al., 1984). Subsequent interactions with the GABA receptor could act to guide the axon to its correct target and increase the likelihood of synaptic formation.

A third role for GABA, particularly in the postnatal period, may be in acting via $\mathrm{GABA}_{\mathrm{A}}$ receptors to interact with other neurotransmitter receptors in order to control rates of neuronal differentiation or to enhance specific axon pathway synaptogenesis. Evidence has accumulated recently that the NMDA glutamate receptor subtype is of primary importance in activitydependent segregation of geniculate afferents in cat striate cortex that occurs between P2wk and P6wk (Tsumoto et al., 1986; Kleinschmidt et al., 1987; Rauschecker and Hahn, 1987; Fox et al., 1989). If one eyelid is closed during this period, most neurons in cat layer 4 are driven by the open eye, but if NMDA receptors are blocked at the time the eyelid is closed, no such shift takes place (Kleinschmidt et al., 1987; Rauschecker and Hahn, 1987). The NMDA receptor is voltage gated and is rendered ineffective if the neuron is hyperpolarized by GABA (Mayer et al., 1984), so GABA could exert an indirect developmental effect by setting the activity level of the neuron carrying the NMDA receptor. Application of MS in vivo to visual cortex not only prevents the expected ocular dominance shift to the open eye when one eyelid is closed but causes a shift in favor of the closed eye (Reiter and Stryker, 1988). This suggests that GABA and/or postsynaptic activity could have some direct action during these developmental interactions, in addition to affecting NMDA receptors indirectly.

The computation of FZ:MS binding site ratios in different species suggests an evolutionary shift away from $F Z$ binding sites and toward MS binding sites in mammalian cerebral cortex. We found that the monkey ratio is $1: 2-3$ before birth and then rises to 1:4-6 after birth. In human frontal cortex, MS binding also predominates throughout life, with a ratio of $1: 2$ in fetuses and adults, and a peak of 1:4 just before and after birth (Brooksbank et al., 1981, 1982). In adult rat whole brain assays, FZ binding sites dominate those for MS with a ratio of 2:1 (Palacios et al., 1979) and 4:1 in adult rat neocortex (Shaw and Scarth, 1991). Cat visual cortex is intermediate with a ratio of $1.5: 1$ at both P30d and P1yr (Shaw et al., 1987). Our $B_{\max }$ studies in monkey show that in early striate cortex development the FZ: MS binding site ratio is at its highest. If these FZ binding sites are linked to $\mathrm{GABA}_{\mathrm{A}}$ receptors, this suggests greater modulation of GABA binding at early developmental stages. If they are not linked, this suggests the occurrence of a prenatal receptor population that might have a very different function from the classic $\mathrm{GABA}_{\mathrm{A}}$ receptor. Protein analysis and binding of benzodiazepine ligands with different specificities have shown the presence of several peptides in immature rat cortex, but only a single peptide in adult, that bind or are precipitated by ${ }^{3} \mathrm{H}-\mathrm{FZ}$ (Eichinger and Sieghart, 1986; Sato and Neale, 1989a,b; Vitorica et al., 1990). These results also suggest a shift during cortical development from multiple to single forms of the $\mathrm{GABA}_{\mathrm{A}}$ receptor.

Quantitative analysis of film autoradiographs found no changes in MS binding over the first P18wk that could be related to monkey critical period visual developmental changes in layer 4C (Blakemore et al., 1978; LeVay et al., 1980; Wiesel, 1982). 
MS labeling increased rapidly over this period in both layers $4 \mathrm{C}$ and $2 / 3$, and showed no "patchy" patterns. On the other hand, FZ density in layer $4 \mathrm{C}$ showed a peak at P49d and then sharply declined, coincident with the end of the most critical period for ocular dominance development. What role, if any, the FZ binding site plays in layer $4 \mathrm{C}$ thalamocortical interactions remains to be determined. We did note several interesting differences in peak binding measured in layers $2 / 3$ or layer 4 versus whole cortex determinations. First, MS binding in whole cortex shows a greater decline in adulthood than in either layers $2 / 3$ or layer 4 . This probably is due to the marked loss of MS binding sites in infragranular layers seen in the film autoradiographs. FZ hinding sites in whole cortex show a slight decline in adulthood that may be accounted for by a marked decline in layer $4 \mathrm{C}$ coincident with an increase in layers $2 / 3$. Second, we note that the ratios of $\mathrm{MS}$ and $\mathrm{FZ}$ binding in layers $2 / 3$ versus layer 4 change in a reciprocal fashion during development; for instance, between P7wk and P18wk, the highest ratio for MS is coincident with the lowest for FZ. This suggests very different changes in receptor subtypes in the same layer at the same age that may be due to developmental modifications of the receptor subunit composition (Sieghart, 1989; Olsen and Tobin, 1990; Vitorica et al., 1990).

In this article, we have presented the first complete developmental sequence for $\mathrm{GABA}_{\mathrm{A}}$ and $\mathrm{GABA}_{\mathrm{B}}$ receptors in monkey striate cortex. MS and FZ binding sites appear early in development, show a high level in layer 4 as soon as it is formed, and have an adult laminar distribution shortly after birth. BA binding sites are present by midgestation, become slightly lighter in layer 4 with age, and do not change their laminar distribution throughout development. GABA also appears in neurons at the same time that MS and FZ binding sites are detected, but before synapses are present in significant numbers. This suggests a role for $\mathrm{GABA}$ and $\mathrm{GABA}_{\mathrm{A}}$ receptors that is not linked to synaptic activity in the initial stages of cortical development. In later prenatal and in postnatal development, $\mathrm{GABA}_{\mathrm{A}}$ receptor numbers closely follow synaptic density changes, suggesting a closer link to neurotransmission.

\section{References}

Aaltonen L, Erkkola R, Kanto J (1983) Benzodiazepine receptors in the human fetus. Biol Neonate 44:54-57.

Aldinio C, Balzano M, Savoini G, Leon A, Toffano G (1981) Ontogeny of $\left[{ }^{3} \mathrm{H}\right]$-diazepam binding sites in different rat brain areas. Dev Neurosci 4:461-466.

Allman J, McGuinness E (1988) Visual cortex in primates. In: Comparative primate biology, Vol 4 (Steklis HD, Erwin J, eds), pp 279326. New York: Liss.

Baskin DG, Dorsa D (1986) Quantitative autoradiography and in vitro radioligand binding. In: Functional mapping in biology and medicine: computer assisted autoradiography (McEachron D, ed), pp 204-234. Basel: Karger.

Belhage B, Hanse GH, Schousboe A (1990) GABA agonist induced changes in ultrastructure and GABA receptor expression in cerebellar granule cells is linked to hyperpolarization of the neurons. Int J Dev Neurosci 8:473-479.

Blakemore C, Garey LJ, Vital-Durand F (1978) The physiological effects of monocular deprivation and their reversal in monkey's visual cortex. J Physiol (Lond) 283:223-262.

Blasdel GG, Fitzpatrick D (1984) Physiological organization of layer 4 in macaque striate cortex. J Neurosci 4:880-895.

Blue ME, Parnavelas JG (1983) The formation and maturation of synapses in the visual cortex of the rat. II. Quantitative analysis. J Neurocytol 12:697-712.

Boothe RG (1988) Visual development: central neural aspects. In: Handbook of human growth and developmental biology, Vol 1, Pt B (Meisami E, Timiras PS, eds), pp 179-191. Boca Raton, FL: CRC.
Boothe RG, Dobson V, Teller DY (1985) Postnatal development of vision in human and nonhuman primates. Annu Rev Neurosci 8: 495-545.

Bowery N (1989) GABA-B receptors and their significance in mammalian pharmacology. Trends Neurosci 10:401-407.

Braestrup C, Nielsen M (1978) Ontogenetic development of benzodiazepine receptors in the rat brain. Brain Res 147:170-173.

Braestrup C, Albrechtsen R, Squires RF (1977) High densities of benzodiazepine receptors in human cortical areas. Nature 269:702-704.

Brooksbank BWL, Atkinson DJ, Balázs R (1981) Biochemical development of the human brain. II. Some parameters of the GABAergic system. Dev Neurosci 4:188-200.

Brooksbank BWL, Atkinson DJ, Balázs R (1982) Biochemical development of the human brain. III. Benzodiazepine receptors, free gamma aminobutyrate (GABA) and other amino acids. J Neurosci Res $8: 581-594$

Bylund DB (1980) Analysis of receptor binding data. In: Receptor binding techniques, short course syllabus, pp 70-99. Washington, DC: Society for Neuroscience.

Chun JM, Shatz CJ (1989) The earliest-generated neurons of the cat cerebral cortex: characterization by MAP2 and neurotransmitter immunohistochemistry during fetal life. J Neurosci 9:1648-1667.

Costa E, Guidotti A, Toffano G (1978) Molecular mechanisms mediating the action of diazepam on GABA receptors. Brit J Psychiatry 133:239-248.

Coyle JT, Enna SJ (1976) Neurochemical aspects of the ontogenesis of GABAergic neurons in the rat brain. Brain Res 111:119-133.

Eichinger A, Sieghart W (1986) Postnatal development of proteins associated with different benzodiazepine receptors. J Neurochem 46 : 173-181.

Fitzpatrick D, Lund JS, Schmechel DE, Towles AC (1987) Distribution of GABAergic neurons and axon terminals in the macaque striate cortex. J Comp Neurol 264:73-91.

Fox K, Sato H, Daw N (1989) The location and function of NMDA receptors in cat and kitten visual cortex. J Neurosci 9:2443-2454.

Gordon-Weeks PR, Lockerbie RO, Pearce BR (1984) Uptake and release of $\left[{ }^{3} \mathrm{H}\right] \mathrm{GABA}$ by growth cones isolated from neonatal rat brain. Neurosci Lett 52:205-210.

Harwerth RS, Smith EL III, Crawford MLJ, von Noorden GK (1989) The effects of reverse monocular deprivation in monkeys. I. Psychophysical experiments. Exp Brain Res 74:327-337.

Hendrickson AE (1985) Dots, stripes and columns in monkey visual cortex. Trends Neurosci 8:404-410.

Hendrickson AE, Wilson JR, Ogren MP (1978) The neuroanatomical organization of pathways between the dorsal lateral geniculate nucleus and visual cortex in old world and new world primates. J Comp Neurol 182:123-136.

Hendrickson AE, Hunt SP, Wu J-Y (1981) Immunocytochemical localization of glutamic acid decarboxylase in monkey striate cortex. Nature 292:605-607.

Hendrickson AE, Movshon JA, Eggers HM, Gizzi MS, Boothe RG, Kiorpes L (1987) Effects of early unilateral blur on the macaque's visual system. II. Anatomical observations. J Neurosci 7:1326-1339.

Hendrickson AE, Mehra R, Tobin A (1988) In situ hybridization and immunocytochemical labeling of GABA neurons during development of monkey visual cortex. Soc Neurosci Abstr 14:188.

Hendry SHC, Jones EG (1986) Reduction in number of immunostained GABAergic neurons in deprived-eye dominance columns of monkey area 17. Nature 320:750-753.

Hendry SHC, Schwark HD, Jones EG, Yan J (1987) Numbers and proportions of GABA immunoreactive neurons in different areas of monkey cerebral cortex. J Neurosci 7:1503-1520.

Hendry SHC, Fuchs J, deBlas AL, Jones EG (1990) Distribution and plasticity of immunocytochemically localized GABA-A receptors in adult monkey visual cortex. J Neurosci 10:2438-2450.

Horton JC, Hedley-Whyte ET (1984) Mapping of cytochrome oxidase patches and ocular dominance columns in human visual cortex. Philos Trans R Soc Lond [Biol] 304:255-272.

Houser CR, Vaughn JE, Hendry SH, Jones EG, Roberts E (1984) GABA neurons in the cerebral cortex. In: Cerebral cortex, Vol 2, Functional properties of cortical cells (Jones EG, Peters A, eds), pp 63-89. New York: Plenum.

Hubel DH (1982) Exploration of the primary visual cortex, 1955-78. Nature 299:515-524.

Hunston DL (1975) Two techniques for evaluating small molecule- 
macromolecule binding in a complex system. Anal Biochem 63:99109.

Huntley GW, deBlas AL, Jones EG (1990) GABA receptor immunoreactivity in adult and developing monkey sensory-motor cortex. Exp Brain Res 82:519-535.

Kaas.JH, Huerta MF (1988) The subcortical visual system of primates. In: Comparative primate biology, Vol 4 (Steklis HD, Erwin J, eds), pp 327-392. New York: Liss.

Kellogg CK (1988) Benzodiazepines: influence on the developing brain. In: Progress in brain research, Vol 73 (Boer GJ, Feenstra MGP, Mirmiran M, Swaab DF, Van Haaren F, eds), pp 207-228. Amsterdam: Elsevier.

Kiorpes L, Boothe RG, Hendrickson AE, Movshon JA, Eggers HM, Gizzi MS (1987) Effects of early unilateral blur on the macaque's visual system. I. Behavioral observations. J Neurosci 7:1318-1326.

Kleinschmidt A, Bear MF, Singer W (1987) Blockade of "NMDA" receptors disrupts experience-dependent plasticity of kitten striate cortex. Science 238:355-358.

Köller H, Siebler M, Schmalenbach C, Müller H-W (1990) GABA and glutamate receptor development of cultured neurons from rat hippocampus, septal region, and neocortex. Synapse 5:59-64.

Kriegstein AR, Suppes T, Prince DA (1987) Cellular and synaptic physiology and epileptogenesis of developing rat neocortical neurons in vitro. Dev Brain Res 34:161-171.

Kuman RS, Sweetnam PM, Gallombardo PA, Tallman JF (1987) Molecular biology of inhibitory amino acid receptors. Mol Neurobiol 1: 155-189.

Lauder JM (1988) Roles for neurotransmitters in neurogenesis and development. In: Handbook of human growth and developmental biology, Vol 1, Pt A (Meisami E, Timiras PS, eds), pp 53-66. Boca Raton, FL: CRC.

Lauder JM, Han VKM, Henderson P, Verdoorn T, Towle AC (1986) Prenatal ontogeny of the GABAcrgic system in the rat brain: an immunocytochemical study. Neuroscience 19:465-493.

LaVie V, Hendrickson A (1986) Comparison between pre- and postembedding EM immunocytochemistry using antisera to GABA. Soc Neurosci Abstr 12:128.

LeVay S, Wiesel TN, Hubel DH (1980) The development of ocular dominance columns in normal and visually deprived monkeys. $J$ Comp Neurol 191:1-52.

Livingstone MS, Hubel DH (1988) Segregation of form, color, movement and depth: anatomy, physiology and perception. Science 240 : $740-749$.

Lowry OH, Rosebrough NJ, Farr AL, Randall RJ (1951) Protein measurement with the folin phenol reagent. J Biol Chem 193:265275 .

Luhmann HJ, Princc DA (1991) Postnatal maturation of the GABAergic system in rat neocortex. J Neurophysiol 65:247-263.

Lund JS (1988) Anatomical organization of macaque monkey striate visual cortex. Annu Rev Neurosci 11:253-288.

Malherbe P, Sigel E, Persohn E, Richards JG, Möhler H (1990) Functional characteristics and sites of gene expression of the $\alpha_{1}, \beta_{1}, \gamma_{2}$-isoform of the rat $\mathrm{GABA}_{\mathrm{A}}$ receptor. J Neurosci 10:2330-2337.

Matsumoto RR (1989) GABA receptors: are cellular differences reflected in function? Brain Res Rev 14:203-225.

Mayer ML, Westbrook GL, Guthrie PB (1984) Voltage-dependent block by $\mathrm{Mg}^{2+}$ of NMDA responses in spinal cord neurones. Nature 309:261-263.

McCormick DA (1989) GABA as an inhibitory neurotransmitter in human cerebral cortex. J Neurophysiol 62:1018-1027.

McCormick DA, Prince DA (1987) Post-natal development of electrophysiological properties of rat cerebral cortical pyramidal neurons. J Physiol (Lond) 393:743-762.

Meinicke DL, Rakic P (1989) The temporal relationship of GABA and GABA-A/benzodiazepine receptor expression in neurons of the visual cortex of developing rhesus monkeys. Soc Neurosci Abstr 15: 1335.

Mower GD, Christen WG (1989) Evidence for an enhanced role of GABA inhibition in visual cortical ocular dominance of cats reared with abnormal monocular experience. Dev Brain Res 45:211-218.

Needler MC, Shaw C, Cynader M (1984) Characteristics and distribution of muscimol binding sites in cat visual cortex. Brain Res 308 : 347-352.

O'Kusky J, Colonnier M (1982) Postnatal changes in the number of neurons and synapses in the visual cortex (area 17) of the macaque monkey: a stereological analysis in normal and monocularly deprived animals. J Comp Neurol 210:291-306.

Olsen RW, Tobin AJ (1990) Molecular biology of GABA-A receptors. FASEB J 4:1469-1480.

Palacios JM, Niehoff DL, Kuhar MJ (1979) Ontogeny of GABA and benzodiazepine receptors: effects of Triton X100, bromide and muscimol. Brain Res 179:390-395.

Rakic P (1977) Prenatal development of the visual system in rhesus monkey. Philos Trans R Soc Lond [Biol] 278:245-260.

Rakic P, Bourgeois J-P, Eckenhoff MF, Zecevic N, Goldman-Rakic PS (1986) Concurrent overproduction of synapses in diverse regions of the primate cerebral cortex. Science 232:232-235.

Rakic P, Goldman-Rakic PS, Gallager D (1988) Quantitative autoradiography of major neurotransmitter receptors in the monkey striate and extrastriate cortex. J Neurosci 8:3670-3690.

Rauschecker JP, Hahn S (1987) Ketamine-xylazine anaesthesia blocks consolidation of ocular dominance changes in kitten visual cortex. Nature 326:183-184.

Regan JW, Rocske WR, Yamamura HF (1980) The benzodiazepine receptor: its development and its modulation by gamma-aminobutyric acid. J Pharmacol Exp Ther 212:137-143.

Reiter HO, Stryker MP (1988) Neural plasticity without postsynaptic action potential: less active inputs become dominant when kitten visual cortical cells are pharmacologically inhibited. Proc Natl Acad Sci USA 85:3623-3627.

Ribak CE (1978) Aspinous and sparsely-spinous stellate neurons in visual cortex of rats contain glutamic acid decarboxylase. J Neurocytol $7: 461-478$.

Richards JG, Mohler H (1984) Benzodiazepine receptors. Neuropharmacology 23:233-242.

Rotter A, Gorenstein C, Frosthold A (1988) The localization of GA$B A-A$ receptors in mice with mutations affecting the structure and conncctivity of the cerebellum. Brain Res 439:236-248.

Sato TN, Neale JH (1989a) Type I and type II gamma-aminobutyric acid/benzodiazepine receptors: purifications and analysis of novel receptor complex from neonatal cortex. J Neurochem 52:1 1 14-1 122 .

Sato TN, Neale JH (1989b) Immunological identification of multiple $\alpha$-like subunits of the gamma-aminobutyric acid-A receptor complex purified from neonatal rat cortex. J Neurochem 53:1089-1095.

Scharfman HE, Sarvey JM (1987) Responses to GABA recorded from identified rat visual cortical neurons. Neurosci Lett [Suppl] 26:407422.

Schlumpf MD, Richards JG, Lichtensteiger W, Möhler H (1983) An autoradiographic study of the prenatal development of benzodiazepine-binding sites in rat brain. $J$ Neurosci 3:1478-1487.

Shaw C, Cynader M (1986) Laminar distribution of receptors in monkey (Macaca fascicularis) geniculostriate system. J Comp Neurol 248: 301-312.

Shaw C, Cynader M (1988) Unilateral eyelid suture increases GABA-A receptors in cat visual cortex. Dev Brain Res 40:148-153.

Shaw C, Scarth BA (1991) Characterization and differential regulation of GABA-A and benzodiazepine receptors in rat neocortex. Mol Brain Res, in press.

Shaw C, Needler MC, Cynader M (1984) Ontogenesis of muscimol binding sites in cat visual cortex. Brain Res Bull 13:331-334.

Shaw C, Wilkinson M, Cynader M, Needler MC, Aoki C, Hall SE (1986) The laminar distributions and postnatal development of neurotransmitter and neuromodulator receptors in cat visual cortex. Brain Res Bull 16:661-671.

Shaw C, Aoki C, Wikinson M, Prusky G, Cynader M (1987) Benzodiazepine ( ${ }^{3} \mathrm{H}$-flunitrazepam) binding in cat visual cortex: ontogenesis of normal characteristics and the effects of dark rearing. Dev Brain Res 37:67-76.

Shaw C, Prusky G, Cynader M (1988) Surgical undercutting prevents receptor redistribution in developing kitten visual cortex. Visual Neurosci 1:205-210.

Shaw C, Cameron L, Prusky G, Dyck R, Cynader M, Hendrickson A (1989) Pre-and postnatal development of neurotransmitter receptors in monkey visual cortex. Soc Neurosci Abstr 15:1336.

Shaw C, Cameron L, Hendrickson A (1990) Prenatal and postnatal development of $\mathrm{G} A \mathrm{~B} \Lambda$ and benzodiazepine receptors in monkcy visual cortex. Anat Rec 226:92A-93A.

Sidman RL, Rakic P (1973) Neuronal migration, with special reference to developing human brain: a review. Brain Res 62:1-35. 
Sieghart W (1989) Multiplicity of GABA-A benzodiazepine receptors. Trends Neurosci 10:407-411.

Sillito AM (1984) Functional considerations of the operation of GABAergic inhibitory processes in the visual cortex. In: Cerebral cortex, Vol 2, Functional properties of the cortical cells (Jones EG, Peters A, eds), pp 91-117. New York: Plenum.

Skangiel-Kramska J, Kossut M (1984) Increase of GABA receptor binding activity after short lasting monocular deprivation in kitten. Acta Neurobiol Exp (Warsz) 44:33-39.

Somogyi P (1989) Synaptic organization of GABAergic neurons and GABA-A receptors in the lateral geniculate nucleus and visual cortex. In: Neural mechanisms of visual perception (Lam DM-K, Gilbert CD, eds), pp 35-62. The Woodlands, TX: Portfolio.

Somogyi P, Hodgson AJ (1985) Antiserum to gamma-aminobutyric acid. III. Demonstration of GABA in Golgi-impregnated neurons and in conventional electron microscopic sections of cat striate cortex. $J$ Histochem Cytochem 33:249-257.

Somogyi P, Takagi H, Richards JG, Möhler H (1989) Subcellular localization of benzodiazepine/GABA ${ }_{\mathrm{A}}$ receptors in the cerebellum of rat, cat, and monkey using monoclonal antibodies. J Neurosci 9: 2197-2209.

Spoerri PE (1987) GABA-mediated developmental alterations in a neuronal cell line and in cultures of cerebral and retinal neurons. In: Neurotrophic activity of GABA during development (Redburn DA, Schousboe A, eds), pp 189-220. New York: Liss.

Tigges J, Tigges M (1985) Subcortical sources of direct projections to visual cortex. In: Cerebral cortex, Vol 3 (Peters A, Jones EG, eds), pp 351-378. New York: Plenum.

Tsumoto T, Masui H, Sato H (1986) Excitatory amino acid transmitters in neural circuits of the cat visual cortex. J Neurophysiol 55: $469-483$.

Unnerstall JR, Kuhar MJ, Niehoff DL, Palacios JM (1981) Benzo- diazepine receptors are coupled to a subpopulation of GABA receptors: evidence from a quantitative autoradiographic study. J Pharmacol Exp Ther 218:797-804.

Van Eden CG, Mrzljak L, Voorn P, Uylings HBM (1989) Prenatal development of GABAergic neurons in the neocortex. J Comp Neurol 289:213-227.

Van Huizen F, Shaw C, Wilkinson M, Cynader M (1988) Postnatal development and sex differences of muscarinic acetylcholine receptor characteristics in rat cerebral cortex slices. Soc Neurosci Abstr 14: 269.

Vitorica J, Park D, Chin G, deBlas AL (1990) Characterization with antibodies of the gamma aminobutyric acid- $\mathrm{A}$ /benzodiazepine receptor complex during development of the rat brain. J Neurochem 54: 187-194.

Wiesel TN (1982) Postnatal development of the visual cortex and the influence of environment. Nature 299:583-591.

Wolf W, Hicks TP, Albus K (1986) The contribution of GABA-mediated inhibitory mechanisms to visual response properties of neurons in the kitten's striate cortex. J Neurusci 6:2779-2796.

Wolff JR, Joo F, Kasa P (1987) Synaptic, metabolic and morphogenetic effects of GABA in the superior cervical ganglion of rats. In Neurotrophic activity of GABA during development (Redburn DA, Schousboe A, eds), pp 221-252. New York: Liss.

Zecevic N, Bourgeois JP, Rakic P (1989) Changes in synaptic density in motor cortex of rhesus monkey during fetal and postnatal life. Dev Brain Res 50:11-32.

Zielinski B, Hendrickson AE (1990) Development of synapses in macaque monkey striate cortex shows an "inside-out" pattern. Soc Neurosci Abstr 16:494.

Zivin JA, Waud DR (1982) How to analyze binding, enzyme and uptake data: the simplest case, a single phase. Life Sci 30:1407-1422. 